\title{
MOLECULAR PHYLOGENY AND TAXONOMIC REVISION OF THE GENUS WITTROCKIELLA (PITHOPHORACEAE, CLADOPHORALES), INCLUDING THE DESCRIPTIONS OF W. AUSTRALIS SP. NOV. AND W. ZOSTERAE SP. NOV. ${ }^{1}$
}

\author{
Christian Boedeker ${ }^{2}$
}

School of Biological Sciences, Victoria University of Wellington, PO Box 600, Wellington 6140, New Zealand

$$
\text { Charles J. O'Kelly }{ }^{2}
$$

Friday Harbor Laboratories, University of Washington, Friday Harbor, Washington 98250, USA

$$
\text { John A. West }
$$

School of Biosciences 2, University of Melbourne, Parkville, Vic 3010, Australia

Takeaki Hanyuda

Kobe University Research Center for Inland Seas, Rokkodai, Nadaku, Kobe 657-8501, Japan

Adele Neale

School of Biosciences 2, University of Melbourne, Parkville, Vic 3010, Australia

Isamu Wakana

Lake Akan Eco-Museum Center, Akano-onsen 1-1-1, Akan, Hokkaido 085-0467, Japan

Mike D. Wilcox

Botany Department, Auckland Museum, Private Bag 92018, Auckland 1142, New Zealand

\section{Ulf Karsten}

Institute of Biological Sciences, Applied Ecology \& Phycology, University of Rostock, D-18059 Rostock, Germany

\author{
and Giuseppe C. Zuccarello
}

School of Biological Sciences, Victoria University of Wellington, PO Box 600, Wellington 6140, New Zealand

Wittrockiella is a small genus of filamentous green algae that occurs in habitats with reduced or fluctuating salinities. Many aspects of the basic biology of these algae are still unknown and the phylogenetic relationships within the genus have not been fully explored. We provide a phylogeny based on three ribosomal markers (ITS, LSU, and SSU rDNA) of the genus, including broad intraspecific sampling for $W$. lyallii and $W$. salina, recommendations for the use of existing names are made, and highlight aspects of their physiology and life cycle. Molecular data indicate that there are five species of Wittrockiella. Two new species, $W$. australis and W. zosterae, are described, both are endophytes. Although W. lyallii and $W$. salina can be identified morphologically, there are no diagnostic morphological characters

\footnotetext{
${ }^{1}$ Received 5 September 2016. Accepted 4 December 2016.

${ }^{2}$ Present address: Cyanotech Corporation, 73-4460 Queen Ka'ahamanu Highway, Suite \#102, Kailua Kona, HI 96740, USA.

${ }^{3}$ Author for correspondence: e-mail christian.boedeker@vuw.ac.nz.

Editorial Responsibility: H. Verbruggen (Associate Editor)
}

to distinguish between W. amphibia, W. australis, and $W$. zosterae. A range of low molecular weight carbohydrates were analyzed but proved to not be taxonomically informative. The distribution range of W. salina is extended to the Northern Hemisphere as this species has been found in brackish lakes in Japan. Furthermore, it is shown that there are no grounds to recognize $W$. salina var. kraftii, which was described as an endemic variety from a freshwater habitat on Lord Howe Island, Australia. Culture experiments indicate that $W$. australis has a preference for growth in lower salinities over full seawater. For W. amphibia and $W$. zosterae, sexual reproduction is documented, and the split of these species is possibly attributable to polyploidization.

Key index words: Cladophorella; green algae; karyology; molecular phylogenetics; polyploidy; rDNA; sexual reproduction; taxonomy; Ulvophyceae

Abbreviations: BI, Bayesian Inference; bp, base pairs; ITS, internally transcribed spacer; LSU, large 
ribosomal subunit; ML, maximum likelihood; rDNA, ribosomal DNA; SSU, small ribosomal subunit

Wittrockiella Wille is a poorly known genus of branched filamentous green algae with few species that occur predominantly in brackish environments. It is a fascinating genus with regard to morphology, habitats, and distributions. Wittrockiella contains taxa with such an unusual combination of characteristics that Wille (1909), when he described the type species, Wittrockiella amphibia (Collins) Boedeker \& Hansen ( $=W$. paradoxa Wille), placed it in its own family, the Wittrockiellaceae. Wittrockiella was originally placed in the order Chaetophorales, which included algae that have branched filaments and produce both hairs and orange akinete-like cells. Fritsch (1935), however, placed this genus in the Cladophorales because the cells are multinucleate and have reticulate chloroplasts. Fritsch's assessment has been supported by recent molecular studies (Hanyuda et al. 2002, Yoshii et al. 2004, Boedeker et al. 2012). The genus is now placed within the family Pithophoraceae, which is sister to the Siphonocladus clade and the Cladophoraceae (Boedeker et al. 2012).

The simple filamentous morphology of the Cladophorales without specialized structures results in few diagnostic morphological characters, and in addition phenotypic plasticity and convergent evolution are widespread in this order (van den Hoek 1963, Leliaert and Boedeker 2007, Leliaert et al. 2009a,b, Boedeker et al. 2012, 2016). Therefore, the Cladophorales are notorious for being a systematic challenge, and taxonomic confusion exists at all levels, from species and genera to families and orders. However, with the use of molecular data progress in our understanding of the evolutionary history of the Cladophorales has been made, and the taxonomy has been adapted accordingly in recent years (Leliaert et al. 2009a,b, Boedeker et al. 2012, 2016, Ichihara et al. 2013).

In addition to the mainly brackish genus Wittrockiella, the Pithophoraceae contains several speciespoor, predominantly freshwater genera: Aegagropila, Aegagropilopsis, Arnoldiella (Basicladia), and Pithophora. Wittrockiella is typically found in habitats with reduced or fluctuating salinity (e.g., saltmarshes, mangroves, intertidal rocks with freshwater influx, brackish lakes), but also freshwater waterfalls and moist soil surfaces.

The members of this genus share a heterotrichous growth form, with creeping main axes that produce relatively short upright filaments. There is no holdfast, but rhizoids can be formed in all cells along stolonoid axes, and can develop from any part of the cell. The heterotrichous thallus organization is thought to be an adaptation to cope with changeable environments, as the prostrate stratum of filaments is more protected, retains more moisture, and can persist during unfavorable conditions while the upright filaments allow for harvesting light (Fritsch 1944, Boedeker 2010, Boedeker and Hansen 2010). Still little is known of the morphological variability in species of Wittrockiella, and features of reproduction, karyology, life history, or cytology at the light or electron microscopic levels remain virtually unknown. Wittrockiella currently contains seven described species (two of them have two varieties), after molecular data led to the inclusion of Cladophorella (Boedeker et al. 2012). The species have traditionally been separated on the basis of vegetative cell dimensions (Chapman 1949, 1956, Islam 1964, van den Hoek et al. 1984, Galicia-García and Novelo 2000).

The type species Wittrockiella amphibia occurs in salt marshes on the Atlantic coasts of Europe (Wille 1909, Polderman 1976, Calvo et al. 1999, Hardy and Guiry 2003) and North America (Collins 1912, South 1989) and has been reported from the Pacific coast of North America (Collins 1907, South 1981, Boedeker and Hansen 2010). The alga was originally found on salt marsh soils, but both Polderman (1976) and South $(1981,1989)$ also found it endophytic in salt marsh phanerogams. Wittrockiella calcicola (Fritsch) Boedeker is a (sub) tropical sub-aerial species that was described from a greenhouse in the Cambridge Botanical Gardens (as Cladophorella calcicola; Fritsch 1944) on moist limestone. The species has also been reported from a semi-marine cavern in Australia (Cribb 1965), as well as from moist stone and mud and twigs in Bangladesh (as var. calcicola; Islam 1964), and also from freshwater environments in China (Liu 1999). Two more species have been described from the Indian subcontinent, W. fritschii (A.K. Islam) Boedeker growing on moist stones and twigs and W. sundarbanensis (A.K. Islam) Boedeker growing on mud surfaces in brackish waters, both originally placed in Cladophorella. Also Wittrockiella netzhualpillii (Galicia \& Novelo) Boedeker, previously in Cladophorella, is only known from a single location, an inland brackish water well in Mexico, and differs from the other members of the genus in its mode of spore formation (GaliciaGarcía and Novelo 2000). Wittrockiella salina V.J. Chapman has been reported from marine intertidal and brackish environments in New Zealand and Australia (Chapman 1949, 1956, van den Hoek and Womersley 1984, van den Hoek et al. 1984). Another species from New Zealand, Cladophorella marina Chapman, was later synonymized with W. salina (Beanland and Woelkerling 1982). In a few brackish ponds in Gippsland, southeastern Australia, W. salina forms floating balls of intertwined filaments (van den Hoek et al. 1984), similar to the lake balls of Aegagropila linnaei Kützing (see Niiyama 1989, Boedeker et al. 2010b). Wittrockiella salina is reported in one freshwater location, an inland waterfall on the remote Australian Lord Howe Island, and this population has been described as 
the endemic variety W. salina var. kraftii Skinner \& Entwisle (Skinner and Entwisle 2004). Wittrockiella lyallii (Harvey) C. Hoek et al. has a disjunct distribution between southern New Zealand and southern Chile (Chapman 1956, Adams 1994, Boedeker et al. 2010a), and previously was placed in Cladophoropsis (as C. lyallii (Harvey) Chapman and C. brachyarthra (Svedlius) Wille). As is characteristic for Wittrockiella, this species typically occurs in habitats with reduced salinity, such as intertidal rocks under overhanging vegetation in high rainfall areas or brackish bays and fjords of almost freshwater character (Svedelius 1900, Nelson et al. 2002, Boedeker et al. 2010a). Morphologically, $W$. lyallii is the most distinct species of the genus, with coarse filaments up to $740 \mu \mathrm{m}$ in diameter (Boedeker et al. 2010a).

Molecular phylogenies have shown that Wittrockiella lyallii is sister to the rest of Wittrockiella, but very few sequence data are available for the genus and only six specimens were included (Boedeker et al. 2012). An unidentified species from Australia that did not conform to the descriptions of $W$. salina or $W$. calcicola was shown to be closely related to $W$. amphibia (Boedeker et al. 2012). There are no molecular data for $W$. calcicola (despite a sequenced specimen labeled $W$. calcicola in Boedeker et al. 2012, see discussion of this study), W. fritschii, W. netzhualpilii, W. salina, and W. sundarbanensis.

In this study, we have considerably increased the taxon sampling and aim to clarify the phylogenetic relationships of the species of Wittrockiella based on SSU, LSU, and ITS rDNA sequences, to investigate the genetic variation within species, to re-assess our knowledge of distribution ranges and to revise the taxonomy of the genus.

\section{MATERIALS AND METHODS}

Taxon sampling and morphological identification. More than 70 specimens of Wittrockiella were investigated in the course of this and earlier studies (Table S1 in the Supporting Information). Of those, 24 collections of Wittrockiella were selected and used for the phylogenetic analyses (Table 1), including nine collections each for $W$. salina and $W$. lyallii that cover (and extend) their known distributional range. Samples of $W$. salina included the unattached ball-form from Gippsland, the freshwater variety from a waterfall on Lord Howe Island, as well as novel findings of this species from brackish lakes in Japan. In addition to multiple samples from mainland New Zealand, collections of W. lyallii included Stewart Island, the Chatham Islands, the sub-Antarctic Snares Islands as well as two collections from Chile. These specimens, either fresh, preserved in formalin or ethanol, or reconstituted from herbarium material, were examined with an Olympus SZX10 stereomicroscope and an Olympus BH2 light microscope (Olympus Optical Co. GmbH, Hamburg, Germany), and images were taken with a connected digital camera (ColorView Illu, Olympus Soft Imaging Systems, Münster, Germany). All specimens were identified morphologically, as far as possible.

Two unidentified specimens from Australian mangroves were collected at the same site at different times of the year as endophytes in the bark of Avicennia marina (Forssk.) Vierh. pneumatophores and subsequently isolated into unialgal cultures (samples B92 and Q81; Table 1). One of these collections was used for culture experiments to infer environmental preferences (see below).

Sample N77 (=culture collection CCMP/NCMA1672) was previously identified, incorrectly, as Chaetosiphon moniliformis Huber (O'Kelly and Floyd 1981, 1984, O'Kelly 1982, Chappell et al. 1991), and was investigated karyologically and cytologically, together with the superficially similar sample N60 (W. amphibia, culture collection CCMP/NCMA1672). Both samples N77 and N60 were cultured in f/2 enriched seawater medium (Guillard and Ryther 1962) and incubated in controlled-environment chambers at $10^{\circ} \mathrm{C}, 15^{\circ} \mathrm{C}$, or $20^{\circ} \mathrm{C}$ under fluorescent photon fluence rates $(5-20 \mu \mathrm{mol}$ photons $\cdot \mathrm{m}^{-2} \cdot \mathrm{s}^{-1}, 14: 10 \mathrm{~h}$ light:dark photoperiod). Cultures were treated with $\mathrm{GeO}_{2}\left(0.5 \mu \mathrm{g} \cdot \mathrm{mL}^{-1}\right.$ culture medium final concentration), and streptomycin and/or penicillin G $\left(80 \mu \mathrm{g} \cdot \mathrm{mL}^{-1}\right.$ culture medium final concentration) as needed to suppress diatom and cyanobacterial growth.

Culture experiments. Material from an unidentified species of Wittrockiella (sample number Q81) was isolated into unialgal cultures excised from an Avicennia pneumatophore and used for culture experiments under different environmental conditions. The treatments lasted for 10 weeks. Experiments were carried out in six-well trays with $10 \mathrm{~mL}$ of culture medium in each well at ambient temperatures of $17^{\circ} \mathrm{C}-22^{\circ} \mathrm{C}$. In total, eight trays were used (the equivalent of 48 wells). Each well was inoculated with $0.5 \mathrm{~mL}$ from a freshly shaken container of $30 \mathrm{~mL}$ vortexed stock culture of suspended filaments. Half of the trays were incubated without movement (stationary) and the other half on a shaker at $70 \mathrm{rpm}$. Two environmental variables were tested, irradiance levels and salinity. In both stationary and shaking set-ups, two trays contained full strength salinity medium (salinity of 30) and two trays contained low salinity culture medium (salinity of 5). In each set-up, both salinity treatments were exposed to high irradiance $\left(28-31 \mu \mathrm{mol}\right.$ photons $\left.\cdot \mathrm{m}^{-2} \cdot \mathrm{s}^{-1}\right)$ and to low irradiance $\left(4-5 \mu \mathrm{mol}\right.$ photons $\left.\cdot \mathrm{m}^{-2} \cdot \mathrm{s}^{-1}\right)$. Of the six wells in each tray, wells 1-4 contained only algal filaments and culture medium, well 5 contained a thin piece of balsa wood and well 6 contained a piece of nylon mesh $(150 \mu \mathrm{m}$ mesh). The balsa wood and the nylon mesh were added to see whether spores settlement and germination success would differ on a range of substrates. After 10 weeks, the number of colonies was counted in each well. A colony was defined as a tuft of filaments that was visible to the naked eye; thus, unbranched germlings were not counted. For each of the eight treatments (the eight possible combinations of stationary vs. shaking culture, low vs. high irradiance, low vs. high salinity), the number of colonies of the four wells without additional substrate were pooled, and mean values with standard deviations were calculated. For the counts of colonies in the wells with added balsa wood or nylon mesh as substrates only, the absolute numbers of a single well per treatment were available.

Karyological analyses. Chromosome counts of Wittrockiella amphibia (sample number N60) and Wittrockiella material isolated from Zostera leaves (sample number N77) were made on cells mounted on microscope slides, drained of free water with paper towels, and placed directly into Wittmann's hematoxylin (Wittmann 1965) prepared without chloral hydrate. Images were captured from cells mounted in the stain or cleared after staining with $45 \%$ glacial acetic acid.

Molecular markers and phylogenetic analyses. A total of 24 samples was used in the phylogenetic analyses (Table 1), 23 collections of Wittrockiella and one from the outgroup (Pseudocladophora conchopheria (Sakai) Boedeker, Pithophoraceae). 
TABLE 1. Specimens of Wittrockiella used in the phylogenetic analyses with collection data and GenBank accession numbers (sequences generated in this study are indicated in bold). Pseudocladophora conchopheria was used as outgroup. n.i. = no information.

\begin{tabular}{|c|c|c|c|c|c|c|c|}
\hline $\begin{array}{l}\text { Species } \\
\text { n }\end{array}$ & Sample & Habitat & Location & ITS1 & ITS2 & LSU & SSU \\
\hline $\begin{array}{l}\text { Pseudocladophora } \\
\text { conchopheria } \\
\text { Boedeker \& Leliaert }\end{array}$ & K99 & & Shimoda, Japan & KY593940 & KY593940 & FR719951 & $\mathrm{AB} 062705$ \\
\hline Wittrockiella amphibia & N60 & $\begin{array}{l}\text { Epiphytic, } \\
\text { saltmarsh }\end{array}$ & $\begin{array}{l}\text { Lopez Island, } \\
\text { Washington, USA }\end{array}$ & KY593941 & GU384876 & GU384874 & AB078732 \\
\hline W. amphibian & N73 & Estuary, on mud & $\begin{array}{l}\text { Yaquina Bay, Oregon, } \\
\text { USA }\end{array}$ & n.i. & GU384875 & GU384873 & GU384872 \\
\hline $\begin{array}{l}\text { Wittrockiella australis } \\
\text { West \& Boedeker sp. } \\
\text { nov. }\end{array}$ & B92 & $\begin{array}{l}\text { Avicennia } \\
\text { (November) }\end{array}$ & $\begin{array}{l}\text { Jawbone Reserve, } \\
\text { Victoria, Australia }\end{array}$ & n.i. & KY593942 & FR719943 & FR719931 \\
\hline Wittrockiella australis & Q81 & Avicennia (July) & $\begin{array}{l}\text { Jawbone Reserve, } \\
\text { Victoria, Australia }\end{array}$ & KY593943 & KY593943 & KY593960 & KY593973 \\
\hline $\begin{array}{l}\text { Wittrockiella "calcicola" } \\
=W . \text { zosterae sp. nov. }\end{array}$ & K92 & Estuarine/brackish & $\begin{array}{l}\text { Lagoa de Óbidos, } \\
\text { Portugal }\end{array}$ & n.i. & KY593944 & FR719944 & FR719932 \\
\hline $\begin{array}{l}\text { Wittrockiella salina } \mathrm{V} . \mathrm{J} \text {. } \\
\text { Chapman }\end{array}$ & N88 & Intertidal & Kakamatua, New Zealand & n.i. & KY593945 & n.i. & KY593974 \\
\hline W. salina & P71 & Intertidal & Kakamatua, New Zealand & n.i. & KY593946 & KY593961 & KY593975 \\
\hline W. salina & P98 & Intertidal & $\begin{array}{l}\text { Waitemata Harbour, } \\
\text { Auckland, New Zealand }\end{array}$ & n.i. & n.i. & KY593962 & KY593976 \\
\hline W. salina & Q67 & Intertidal & $\begin{array}{l}\text { Tasman Bay, New } \\
\text { Zealand }\end{array}$ & KY593947 & KY593947 & KY593963 & KY593977 \\
\hline W. salina var. kraftii & S34 & $\begin{array}{l}\text { Freshwater } \\
\text { (waterfall) }\end{array}$ & $\begin{array}{l}\text { Lord Howe Island, } \\
\text { Australia }\end{array}$ & KY593948 & KY593948 & KY593964 & KY593978 \\
\hline W. salina & $\mathrm{S} 72$ & Brackish & Lake Shinji, Japan & KY593949 & KY593949 & KY593965 & KY593979 \\
\hline W. salina (ball) & Seq3 & Estuarine/brackish & Lake Bunga, Australia & KY593950 & n.i. & n.i. & KY593980 \\
\hline W. salina & Seq 4 & Estuarine/brackish & Nelson Lagoon, Australia & KY593951 & n.i. & n.i. & KY593981 \\
\hline W. salina & Seq 5 & Brackish & Lake Ogawara, Japan & KY593952 & n.i. & n.i. & KY593982 \\
\hline Wittrockiella lyallii & $\mathrm{H} 67$ & Estuary & $\begin{array}{l}\text { Bradshaw Sound, New } \\
\text { Zealand }\end{array}$ & n.i. & GU220712 & FN257512 & $\mathrm{AB} 062717$ \\
\hline W. lyallii & K76 & Freshwater run-off & Catlins, New Zealand & n.i. & GU936796 & KY593966 & KY593983 \\
\hline W. lyallii & N61 & $\begin{array}{l}\text { Freshwater } \\
\text { seepage }\end{array}$ & Dring Island, Chile & n.i. & GU198504 & GU198503 & GU198502 \\
\hline W. lyallii & N79 & Intertidal & Traiguen, Chile & KY593953 & KY593953 & KY593967 & KY593984 \\
\hline W. lyallii & N89 & Nairn river estuary & $\begin{array}{l}\text { Chatham Islands, New } \\
\text { Zealand }\end{array}$ & n.i. & KY593954 & KY593968 & KY593985 \\
\hline W. lyallii & P59 & (drift) & $\begin{array}{l}\text { Stewart Island, New } \\
\text { Zealand }\end{array}$ & n.i. & KY593955 & KY593969 & KY593986 \\
\hline W. lyallii & P60 & Freshwater layer & $\begin{array}{l}\text { Breaksea Sound, New } \\
\text { Zealand }\end{array}$ & n.i. & KY593956 & KY593970 & KY593987 \\
\hline W. lyallii & R16 & Rocky ledge & $\begin{array}{l}\text { Snares Island, New } \\
\text { Zealand }\end{array}$ & KY593957 & KY593957 & KY593971 & KY593988 \\
\hline W. lyallii & Seq7 & Freshwater layer & $\begin{array}{l}\text { Milford Sound, New } \\
\text { Zealand }\end{array}$ & KY593958 & KY593958 & n.i. & $\mathrm{AB} 062717$ \\
\hline $\begin{array}{l}\text { Wittrockiella zosterae sp. } \\
\text { nov. }\end{array}$ & N77 & $\begin{array}{l}\text { Endophytic in } \\
\text { Zostera }\end{array}$ & $\begin{array}{l}\text { Whiffen spit, Lopez } \\
\text { Island, Washington, } \\
\text { USA }\end{array}$ & KY593959 & KY593959 & KY593972 & KY593989 \\
\hline
\end{tabular}

Most samples were taken from cultured or field-collected specimens which were preserved in silica gel, but DNA was also extracted from ethanol-preserved or herbarium specimens. Total genomic DNA was isolated using the Chelex method (Goff and Moon 1993). Molecular phylogenetic analyses were based on nuclear-encoded small subunit (SSU) and partial large subunit (LSU) rDNA sequences as well as on the more variable internally transcribed spacer regions ITS1 and ITS2. The first $\sim 590$ nucleotides of the LSU rDNA were amplified using the universal primers $\mathrm{C}^{\prime} 1$ forward and $\mathrm{D} 2$ reverse (Hassouna et al. 1984, Leliaert et al. 2003). About 1,700 base pairs (bp) of the SSU rRNA gene were amplified using the primer pairs SR1-SS11H and SSU897-18SC2 (Leliaert et al. 2007). The whole ITS region was amplified with the primers $9 \mathrm{~F}$ and $7 \mathrm{R}$ (Hayakawa et al. 2012), resulting in $\sim 1,000$ bp long fragments. The length of the ITS1 region ranged from 368 to $427 \mathrm{bp}$ and the length of the ITS2 region ranged from 331 to $369 \mathrm{bp}$, respectively, between Wittrockiella species. For some samples, the ITS1 and ITS2 regions were amplified separately (Table 1). ITS1 was amplified using the primer pair ITS5-ITS2 and ITS2 was amplified using the primer pair ITS3-ITS4 (White et al. 1990).

PCR amplifications were carried out with an initial denaturation step of $94^{\circ} \mathrm{C}$ for $5 \mathrm{~min}$ followed by 30-34 cycles of $1 \mathrm{~min}$ at $94^{\circ} \mathrm{C}, 1 \mathrm{~min}$ at $56^{\circ} \mathrm{C}-57^{\circ} \mathrm{C}$ for the LSU and SSU primers or at $63^{\circ} \mathrm{C}$ for the primers for the whole ITS region (9F and $7 \mathrm{R}$, see below) or at $50^{\circ} \mathrm{C}-54^{\circ} \mathrm{C}$ for the ITS1 and ITS2 primers, and $1 \mathrm{~min}$ at $72^{\circ} \mathrm{C}$, and a final extension step of $5 \mathrm{~min}$ at $72^{\circ} \mathrm{C}$. The reaction volume was $25 \mu \mathrm{L}$ and consisted of $\sim 0.1-0.4 \mu \mathrm{g}$ genomic DNA, $1.25 \mathrm{nmol}$ of each dNTP, 6 pmol of each primer, $1 \times$ reaction buffer, $1-2.5 \mathrm{mM} \mathrm{MgCl}_{2}$, $0.005 \%$ BSA, up to $5 \mu \mathrm{L} 5 \mathrm{M}$ betaine, and one unit of Taq polymerase. The annealing temperature for the primer pair ITS1/ITS2 as well as the amounts of $\mathrm{MgCl}_{2}$ and betaine 
varied depending on the amplification success of particular specimens. Amplifications were checked for correct size by electrophoresis on $1 \%$ agarose gels. PCR products were purified with Montage PCR filter units (Millipore, Billerica, MA, USA) or with ExoSAP-IT ${ }^{\circledR}$ (USB Corporation, Cleveland, OH, USA). Cleaned PCR products were commercially sequenced (Macrogen, Seoul, Korea). The obtained sequences have been deposited in GenBank (Table 1).

The LSU and SSU sequences were aligned separately using MUSCLE (Edgar 2004) and then edited by eye in Se-Al v2.0a11 (Rambaut 2007). ITS sequences were too divergent between species to be aligned manually; therefore, two separate approaches were taken: one dataset was created only containing the less variable and thus alignable $5.8 \mathrm{~S}$ region that separates the two spacers, and another dataset was created for the spacer regions using an automated alignment that is based on secondary structure predictions (Q-INS-i, MAFFT version 5; Katoh et al. 2005). For the final analyses, all markers were used in a concatenated dataset, resulting in one alignment containing the SSU, LSU, and $5.8 \mathrm{~S}$ sequences (alignment length 2,525 bp) and another alignment containing the SSU, LSU, and ITS sequences (alignment length $3,582 \mathrm{bp})$. Both datasets were analyzed using Bayesian Inference (BI; Ronquist and Huelsenbeck 2003) and Maximum Likelihood (ML). Corrected pairwise distances were calculated in PAUP* 4.0b10 (Swofford 2002) for the LSU, SSU, and ITS datasets separately, with outgroup taxa in- or excluded. The concatenated datasets were partitioned into SSU, LSU, 5.8S and SSU, LSU, ITS1, 5.8S, ITS2 in the BI analyses, respectively, applying unlinked models of nucleotide evolution to each partition, with GTR $+\mathrm{I}+$ as the initial model for each partition. BI was performed with MrBayes v3.1.2 (Ronquist and Huelsenbeck 2003) and consisted of two parallel runs of one cold and three incrementally heated chains each, and 4 million generations sampled every 100 generations. Posterior probabilities were obtained using a Metropolis-coupled Markov chain Monte Carlo approach. The average standard deviation of the split frequencies of the two parallel runs indicated that the tree samples became increasingly similar and that a stationary distribution was reached (split frequencies $=0.0026$ and 0.0019, respectively). The $\log$ files of the runs were also checked with Tracer $\mathrm{v}$ 1.4.1 (Rambaut and Drummond 2007), and a burnin sample of 10,000 trees was removed from the 40,000 retained trees before calculating the majority rule consensus trees in MrBayes. ML analyses were performed with unpartitioned datasets containing the SSU, LSU, and 5.8S regions (due to missing data effects in partitioned analyses with this methodology; however, for comparison, a partitioned dataset was also run with the two specimens with missing data excluded) using RAxML version 8 (Stamatakis 2014), GTR + I + G was used as the model of evolution. The reliability of the ML topologies was evaluated based on 1,000 nonparametric bootstrap replicates (Felsenstein 1985). The trees were visualized using FigTree v 1.2.2. (Rambaut 2008).

Low molecular weight carbohydrate content. The low molecular weight carbohydrate (LMWC) content of 10 individuals representing five Wittrockiella species was analyzed (Table S2 in Supporting Information) and the LMWCs were extracted from dried algal material. Dry algal samples each of 5-30 mg were extracted with $70 \%$ aqueous ethanol (v/v) in capped centrifuge tubes at $70^{\circ} \mathrm{C}$ in a water bath for $4 \mathrm{~h}$ according to Karsten et al. (1991). After centrifugation for $5 \mathrm{~min}$ at $5,000 \mathrm{~g}, 700 \mu \mathrm{L}$ of the supernatant was evaporated to dryness under vacuum (Speed Vac Concentrator SVC 100H, Savant Instruments Inc., Holbrook, NY, USA). Dried extracts were redissolved in $700 \mu \mathrm{L}$ distilled water and vortexed for $30 \mathrm{~s}$. Samples were analyzed with an isocratic Agilent HPLC system (Santa Clara, CA, USA) equipped with a differential refractive index detector. LMWCs were separated and quantified by two HPLC methods in order to maximize peak identification. Separation of polyols, mono-, and disaccharides was performed on a Bio Rad resin-based column (Aminex Fast Carbohydrate Analysis, $100 \times 7.8 \mathrm{~mm}$ ) using a Phenomenex Carbo- $\mathrm{Pb}^{2+}$ $(4 \times 3 \mathrm{~mm})$ guard cartridge. LMWCs were eluted with $100 \%$ HPLC grade water at a flow rate of $1 \mathrm{~mL} \cdot \min ^{-1}$ at $70^{\circ} \mathrm{C}$ (modified after Karsten et al. 1991). Separation of heterosides and polyols was performed on a Phenomenex resin-based column Rezex ROA-Organic Acid $(300 \times 7.8 \mathrm{~mm})$ protected with a Phenomenex Carbo- $\mathrm{H}^{+}$guard cartridge $(4 \times 3 \mathrm{~mm})$. On the latter column, LMWCs were eluted with $5 \mathrm{mM} \mathrm{H}_{2} \mathrm{SO}_{4}$ at a flow rate of $0.4 \mathrm{~mL} \cdot \mathrm{min}^{-1}$ at $75^{\circ} \mathrm{C}$ (modified after Karsten et al. 2005). LMWCs were identified by comparison of retention times with those of the commercial standard compounds (Roth, Karlsruhe, Germany; Sigma-Aldrich, St. Louis, MO, USA) prepared as $1 \mathrm{mM}$ aqueous solutions and quantified by peak areas. All concentrations are expressed in micromole per gram dry weight.

\section{RESULTS}

Phylogenetic analyses. The phylogenetic trees resulting from the analyses of the concatenated alignments (SSU, LSU, and 5.8S) show five well-supported lineages within Wittrockiella (Fig. 1). The relationship between $W$. lyallii, W. salina, and the clade containing the other three taxa was not resolved with strong support, with only $61 \%$ bootstrap support and no support in the BI analysis (Fig. 1). The relationships of these three lineages could also not be resolved when using the alignment containing SSU, LSU, and the whole ITS region (Fig. S1 in the Supporting Information), or when using partitions in ML (Fig. S2 in the Supporting Information).

Both samples of Wittrockiella amphibia had identical sequences in all three markers except for $7 \mathrm{bp}$ differences in the whole ITS region, and were recovered as sister to a clade that contains a sample from a culture collection labeled W. "calcicola" (sample ACOI_471/K92, originally isolated from a lagoon in Portugal, see below for discussion on the use of this name) and a sample from Washington, USA (sample N77, found endophytically in Zostera leaves). These latter two isolates had identical sequences in all three markers except for $1 \mathrm{bp}$ difference in the ITS2 region, and are described as the new species W. zosterae O'Kelly \& Boedeker sp. nov. (below). Sister to the clade containing $W$. amphibia and $W$. zosterae is a lineage that consists of two identical samples isolated from the bark of mangrove pneumatophores in southern Australia, which is described as the new species W. australis West \& Boedeker sp. nov. (below). Together, these three species form a moderately supported clade.

Pairwise genetic distances between species are large in LSU sequences, with up to $8 \%$ divergence between $W$. lyallii and $W$. salina. The ITS sequences are so different that they cannot be sensibly aligned between species, except for the sister species W. amphibia and $W$. zosterae, which differ by $14 \%$ in the ITS region. 


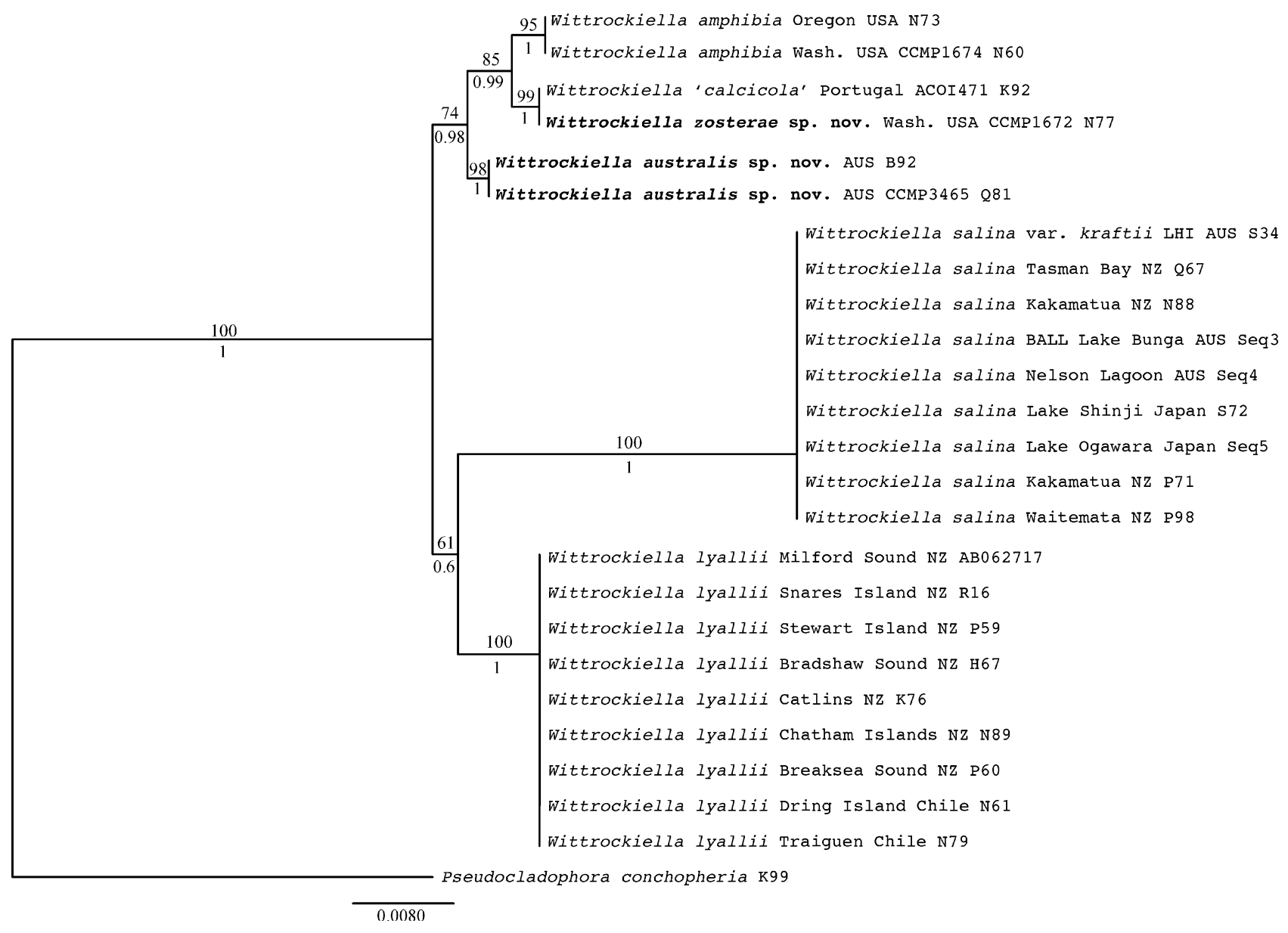

FIG. 1. Bayesian Inference (BI) phylogram of the genus Wittrockiella (Pithophoraceae) inferred from rDNA sequences of the small subunit (SSU), partial large subunit (LSU), and the 5.8S region that separates the internally transcribed spacers. Posterior probabilities from $\mathrm{BI}$ are indicated above the branches, Maximum Likelihood bootstrap values (1,000 replicates) are indicated below. For the BI analysis, the alignment was partitioned into three markers, the ML analysis was run without partitioning. The tree was rooted with Pseudocladophora conchospheria (Pseudocladophoraceae). The positions of Wittrockiella australis sp. nov. and W. zosterae sp. nov. are highlighted in bold. The scale bar represents substitutions per site.

All samples of $W$. lyallii were recovered in a wellsupported clade, and did not show any intraspecific genetic variation in any of the markers throughout their distribution range, which includes distant locations such as New Zealand and Chile, and also isolated locations such as Fiordland, the Chatham Islands, and the sub-Antarctic Snares Islands (New Zealand). Similarly, all samples of W. salina were recovered in a well-supported clade. The LSU and SSU sequences were identical in all samples, and there was only a single variable site in the whole ITS region. The samples of $W$. salina from Lake Bunga (Australia) and from Lake Ogawara (Japan) differed from the samples from Lord Howe Island, Nelson Lagoon (Australia) and Tasman Bay (New Zealand) by one-point mutation (T-C), whereas the specimen from Lake Shinji (Japan) showed both a T and a C signals at that position. The freshwater isolates from Lord Howe Island, previously described as an endemic variety (Skinner and Entwisle 2004), were not genetically distinct, nor was the unique spherical growth form that occurs in the Gippsland Lakes (Australia).

Morphology, culture observations, and karyology. General morphological characterization: Members of the genus Wittrockiella typically have a heterotrichous thallus. A prostrate system of branched uniseriate filaments gives rise to an upright system of thinner, also much branched, uniseriate filaments. Cells in the upright systems tend to be more nearly cylindrical, whereas those in the prostrate system are more irregular in shape. The apical cells of the upright filaments are typically more densely pigmented. Branches are subterminally inserted with delayed cell wall formation. The diameter of the filaments varies greatly between species and the overall range is from 10 to $750 \mu \mathrm{m}$. Reproductive structures are unspecialized cells that transform into aplanosporangia, zoosporangia, or gametangia that release zoids through an elongated exit tube. Such reproductive cells have not yet been found in some species. Enlarged cells are common and may be either 
immature sporangia or akinetes. Colorless non-septate hairs are rarely formed and were only observed in this study in nutrient-depleted cultures. The only attachment structures that are formed are secondary rhizoids, which are typically much thinner than the main filaments and consist of long cells often with a sinuous outline. Rhizoids are typically inserted terminally but lateral rhizoids also occur and can end in haptera. A comparison of the main morphological features is given in Table 2 .

Wittrockiella lyallii: Wittrockiella lyallii consists of coarse filaments (Fig. 2A) that form mats of clearly defined prostrate and upright branch systems (Fig. 2, A and B) in high intertidal areas typically with freshwater influx. It has the largest cell dimensions of all Wittrockiella species, with cell diameters ranging from 250 to $750 \mu \mathrm{m}$. Upright filaments are typically thinner than the prostrate system (Fig. 2B). Growth in culture can lead to more irregular growth patterns, with radial growth in floating tufts (Fig. 2, $\mathrm{C}$ and D). Wittrockiella lyallii often forms secondary rhizoids originating from the apical end of cells (Fig. 2, D and E). Lateral secondary rhizoids are also known, sometimes forming haptera (Fig. 2E). Akinetes, zoidangia, and hairs have never been observed in field or cultured material.

Wittrockiella salina: Wittrockiella salina forms mats in the high intertidal, often at the base of sandstone cliffs in shaded locations, commonly with freshwater seepage or dripping overhanging vegetation (Fig. 3A), or in estuarine environments, but also occurs in other habitats. The mats consist of prostrate filaments giving rise to upright branch systems (Fig. 3B). Cell diameters are variable but are typically less than $200 \mu \mathrm{m}$, and range from 80 to $340 \mu \mathrm{m}$ in upright branches and prostrate filaments, and 60-200 $\mu \mathrm{m}$ in terminal cells. Secondary rhizoids are occasionally formed at the apical pole of cells (Fig. 3C), but they are much less frequent than in W. lyallii. Cultured material shows less distinct separation between upright and prostrate filaments (Fig. 3D), and is more variable in both cell dimensions and cell shape (Fig. 3E). The coarsest filaments are found in the spherical aggregations of W. salina in the Australian Gippsland Lakes (Fig. 3F), where they slightly overlap in their cell dimensions with $W$. lyallii. In the field and cultured material investigated for this study, akinetes, zoidangia, or hairs have never been observed; however, hairs have been reported previously for this species.

Wittrockiella amphibia: Wittrockiella amphibia occurs as mats or tufts on the base of saltmarsh plants, or on or partly buried in the mud in estuarine environments. The prostrate and the upright filaments have similar diameters (Fig. 4A). The cells are typically less than $100 \mu \mathrm{m}$ in diameter, with prostrate filaments ranging from 40 to $70 \mu \mathrm{m}$ and upright filaments ranging from 30 to $50 \mu \mathrm{m}$. Sometimes, swollen cells are observed, and these can be up to $120 \mu \mathrm{m}$ in diameter. Occasionally, short side branches consisting of just one cell, so-called "spurs," are formed (Fig. 4B). Zoidangia have conspicuous long exit tubes, protruding from the center of the cell (Fig. 4C). Thick-walled akinetes are formed solitarily or in short chains within the filaments (Fig. 4D). Long non-septate hairs were only observed in nutrient-depleted cultures (Fig. 4E).

In culture, quadriflagellate zoospores (Fig. S3A in the Supporting Information) released from one thallus were isolated and developed into germlings, of which 18 survived. All 18 individuals produced zoidangia, and in each case the zoidangia produced exclusively biflagellate zoids (Fig. S3B). Two of the 18 individuals were sampled, and in both a chromosome number of 12 was observed (Fig. S3, C and D). Biflagellate zoid germination occurred in none of the 18 progeny while they were grown individually. However, when individuals 1 and 16 and individuals 15 and 17, were placed together germination stages appeared. The germlings were morphologically identical to those produced by quadriflagellate zoospores. These progeny had chromosome numbers of $24 \pm 2$ (Fig. S3, E and F), and reproduced by quadriflagellate zoospores. Thus, $W$. amphibia undergoes sexual reproduction, and has a haploid chromosome number of 12 and a diploid chromosome number of 24. Parthenogenetic development of gametes does not occur.

Wittrockiella zosterae O'Kelly \& Boedeker sp. nov.

Wittrockiella zosterae occurs in estuarine habitats, either endophytic in stems or leaves of salt marsh plants, particularly in dead Zostera leaves (Fig. 5A), or forming mats of heterotrichous filaments on the sediment surface. The irregularly shaped cells observed in endophytic filaments (Fig. 5A) become more regular and develop distinctly branched prostrate and upright filaments in culture (Fig. 5B). Zoidangia have conspicuous long exit tubes that are formed at the terminal (rather than central) poles of the cell (Fig. 5C). Long non-septate hairs were only observed in nutrient-depleted cultures (Fig. 5D), and were typically associated with irregular swollen cells. Cell diameters typically range from 10 to $50 \mu \mathrm{m}$, but can be up to $100 \mu \mathrm{m}$ in swollen cells (Fig. 5D). Cell diameter and shape are very variable both in endophytes and in cultured material (Fig. 5, A and E). Whether swollen cells are culture artifacts, or represent immature zoidangia or akinetes could not be established. Occasionally, terminal rhizoids are formed (Fig. 5F). Only quadriflagellate zoospores were observed in culture (Fig. S4A in the Supporting Information); however, two sets of chromosome numbers, $24 \pm 2$ (Fig. S4B) and 44 (Fig. S4C), were observed in vegetative cells and zoidangia from different plants. It is inferred that $W$. zosterae undergoes sexual reproduction and has a haploid chromosome number of 22-24 and a diploid chromosome number of 44-48.

Description: Irregular green filaments endophytic in stems or leaves of salt marsh plants, including 


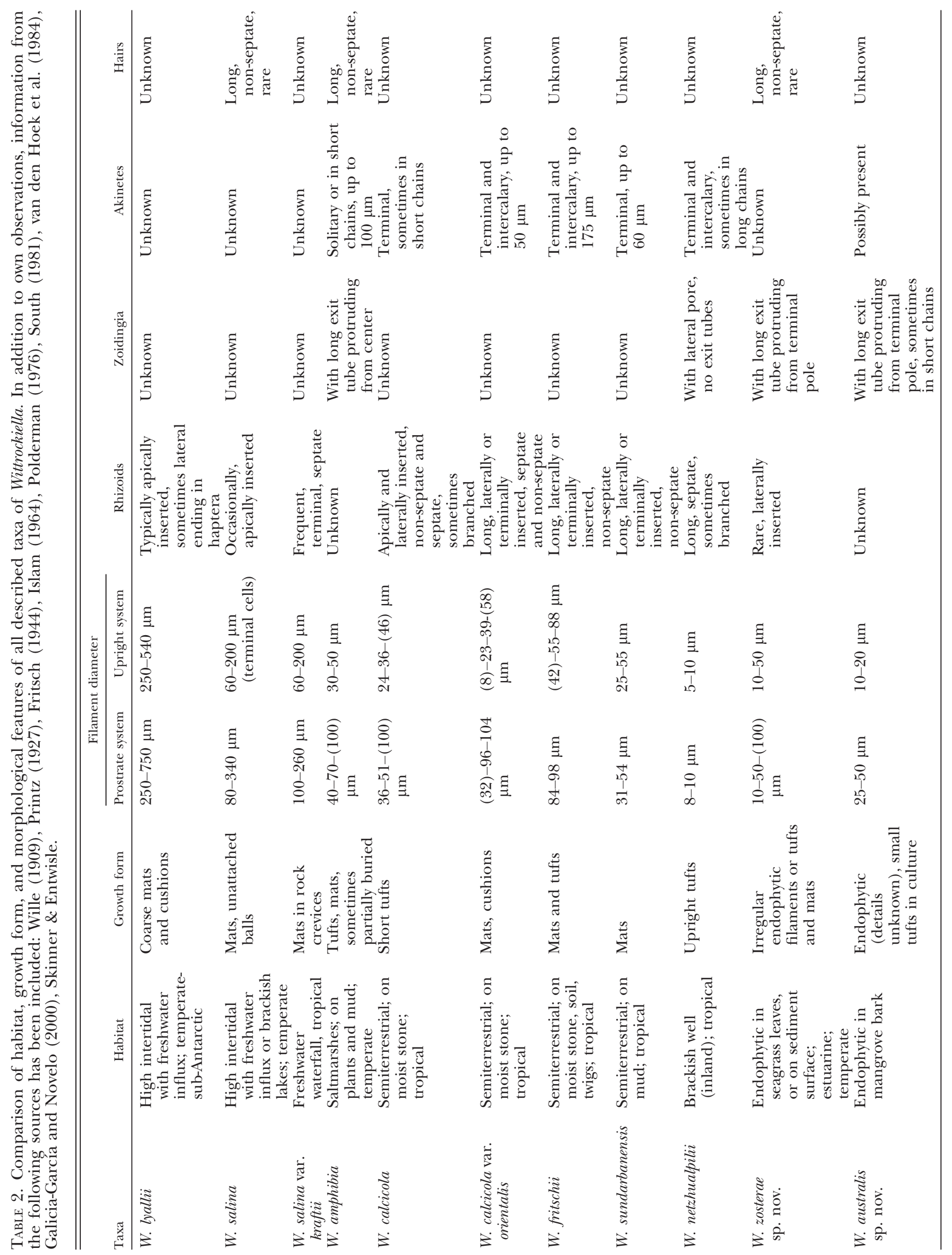


FIG. 2. Morphology of Wittrockiella lyallii. (A) Mat of heterotrichous filaments, with upright filaments arising from an intertwined prostrate stratum. Field collected material from Stewart Island, New Zealand, transferred into culture, scale bar $=1 \mathrm{~cm}$. (B) Heterotrichous thallus: prostrate filament giving rise to upright branch system, with subterminally inserted branches and delayed cross wall formation. Apical cells of upright filaments are more densely pigmented, scale bar $=1 \mathrm{~mm}$. (C) Tuft of filaments grown in culture over 2 years displaying a radial growth pattern, scale bar $=$ $0.5 \mathrm{~cm}$. (D) Main prostrate axis lined with upright filaments of thinner diameter. Few cells have more than one lateral branch. A terminal secondary rhizoid with thinner diameter that was formed at the pole of a cell is indicated (arrow), scale bar $=1 \mathrm{~mm}$. (E) Two different types of secondary rhizoids: a lateral secondary rhizoid (left arrow), and a terminal secondary rhizoid with thinner diameter that was formed at the pole of a cell is indicated (right arrow), scale bar = $500 \mu \mathrm{m}$.

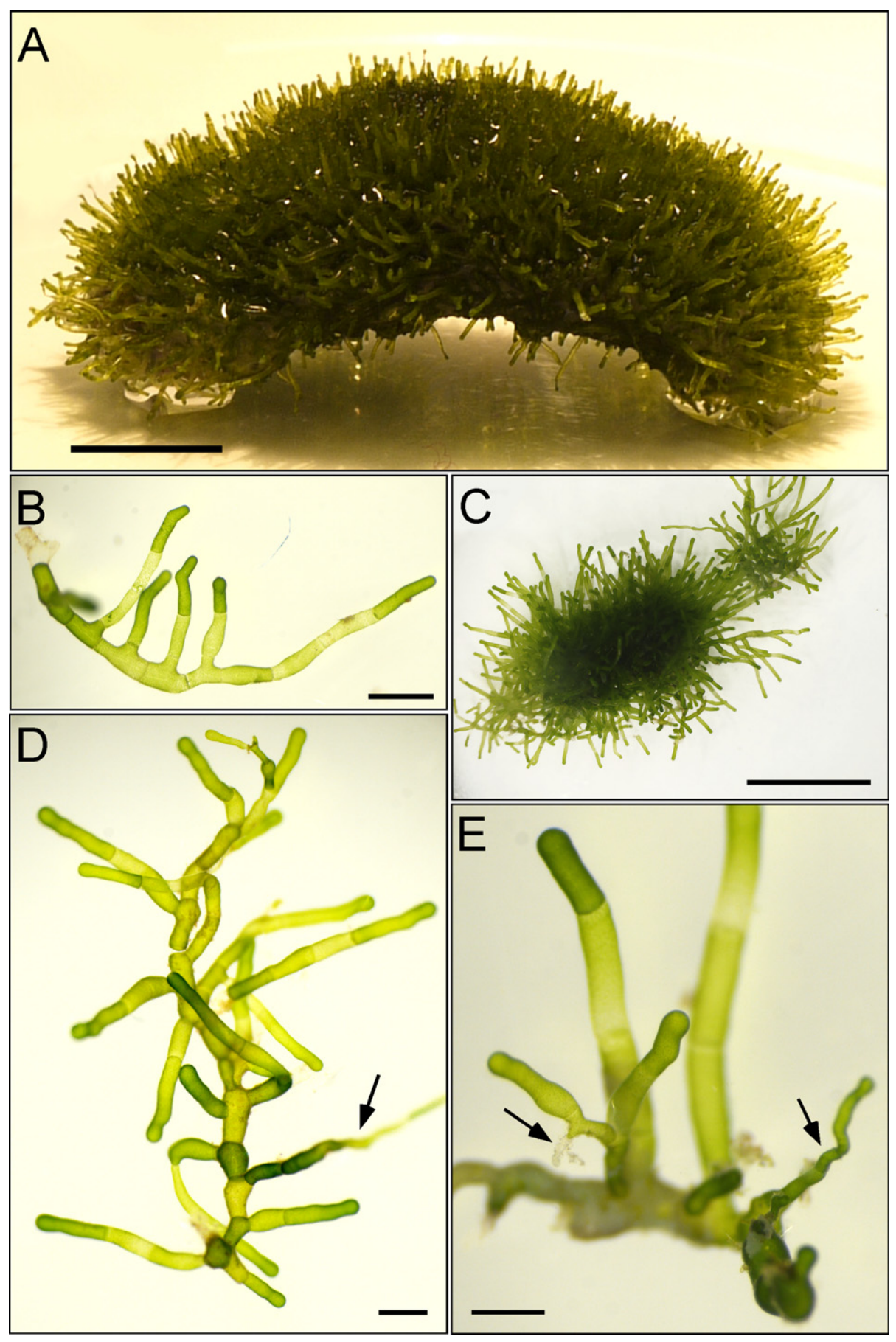

dead Zostera leaves, or as mats of heterotrichous filaments on the sediment surface. Free living and cultured endophytic filaments consist of distinctly branched prostrate and upright systems, with cells $10-50 \mu \mathrm{m}$ in diameter (up to $100 \mu \mathrm{m}$ in swollen cells). Infrequent terminal rhizoids. Zoidangia with conspicuous long, terminal exit tubes. Long nonseptate hairs in nutrient-depleted cultures. Haploid chromosome number 22-24, diploid chromosome number $44-48$.
Etymology: Named after the endophytic habitat of this species inside leaves of the seagrass Zostera.

Holotype: endophytic in Zostera leaves, Sperry Marsh, Lopez Island, Washington, USA, 24 July 1979, C. J. O'Kelly E R. South, National Museum of New Zealand Te Papa Tongarewa (WELT) A031051 (also maintained in culture as CCMP/NCMA1672 at the Provasoli-Guillard National Center for Marine Algae and Microbiota, USA. The holotype specimen has been recently mounted from this culture). 


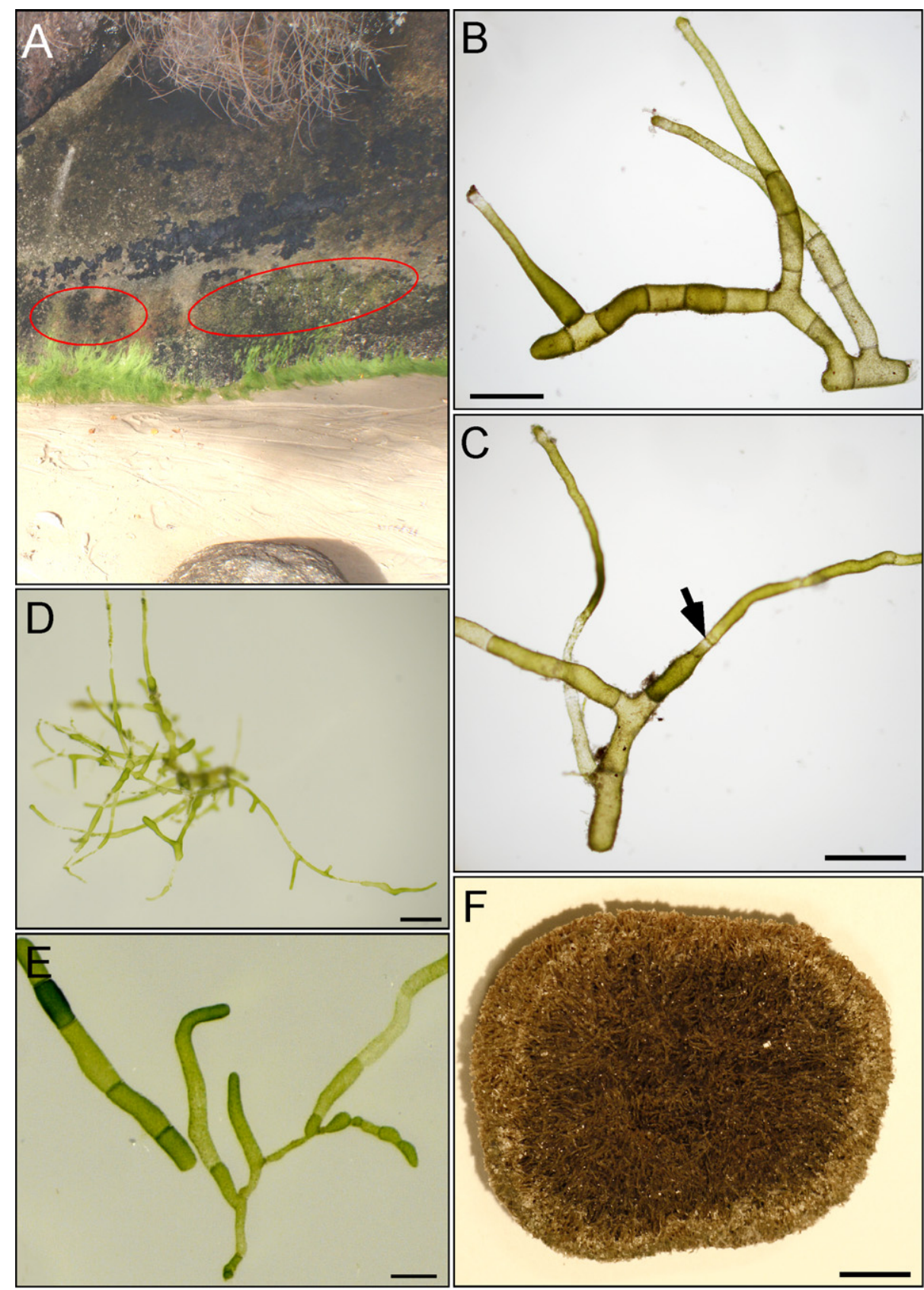

FIG. 3. Morphology of Wit trockiella salina. (A) One of the typical habitats of $W$. salina: high intertidal at the base of sandstone cliffs, in shaded locations, commonly with freshwater seepage or dripping overhanging vegetation, mixed with cyanobacteria, above the Ulva zone and below the lichen zone. The area inhabited by W. salina is outlined in red. Location: Coquille Bay, Tasman Bay, New Zealand. (B) Heterotrichous thallus: prostrate filament giving rise to upright branch system, with subterminally inserted branches and delayed cross wall formation. Apical cell of prostrate filament short and rounded, apical cells of upright filaments are very long and tapering, scale bar $=500 \mu \mathrm{m}$. (C) Terminal secondary rhizoid with thinner diameter and irregular outline (arrow), scale bar = $500 \mu \mathrm{m}$. (D) Irregular growth in culture: separation into prostrate and upright systems becomes indistinct, irregular cells with variable diameters, many rhizoidal cells, scale bar $=1 \mathrm{~mm}$. (E) Irregular growth in culture: strongly varying cell shapes and diameters, scale bar $=500 \mu \mathrm{m}$. $(\mathrm{F})$ Cross section of a herbarium specimen (MEL 597583) of a spherical aggregation of particularly coarse filaments of W. salina, a growth form only known from the Gippsland lakes in Victoria, Australia. The density of filaments is much higher near the surface of the algal ball, scale bar = $1 \mathrm{~cm}$.
Sequence data: GenBank KY593959 (ITS rDNA), KY593972 (LSU rDNA), KY593989 (SSU rDNA).

\section{Wittrockiella australis West \& Boedeker sp. nov.}

This species is currently only known to occur endophytically in the bark of the pneumatophores of the mangrove Avicennia marina (Forssk.) Vierh. In culture, a mixture of swollen cells and long thin filaments develops (Fig. 6A). The swollen cells represent the prostrate filaments which give rise to the thinner upright filaments with much delayed cell wall formation (Fig. 6B). Upright branches can be inserted in terminal or central positions (Fig. 6B). Cell diameters of the prostrate filaments are between 25-50 $\mu \mathrm{m}$, and 10-20 $\mu \mathrm{m}$ in erect branches and cylindrical cells. In culture, attached filaments seem to have longer and thinner cells, and cells seem to have more irregular shapes when compared to unattached filaments (Fig. 6C). Zoidangia have conspicuous long exit tubes that are formed at the terminal poles of the cell, and are sometimes formed in chains (Fig. 6D). Exit tubes in their initial stages are similar to the beginning of lateral branch formation or to the germination of an akinete (Fig. 6, E and F).

In culture, zoidangia were formed and released biflagellate zoids at both high and low salinity, of which only a small percentage germinated. The germlings had the same morphology as the parent 
FIG. 4. Morphological features of Wittrockiella amphibia (Collins) Boedeker et G.I. Hansen. (A) Prostrate filament with developing upright branches, with delayed cross wall formation and slight subterminal branch insertion. Apical cells of upright filaments are more densely pigmented, scale bar $=200 \mu \mathrm{m}$. (B) Cells producing spur-like outgrowths, scale bar $=100 \mu \mathrm{m}$. (C) Empty zoidangium with conspicuous discharge tube, scale bar $=100 \mu \mathrm{m}$. $\quad$ (D) Akinetes arranged solitarily or in short chains, scale bar $=100 \mu \mathrm{m}$. (E) Hair cell in nutrient-depleted culture. Differential interference contrast (DIC) optics, scale bar = $100 \mu \mathrm{m}$.

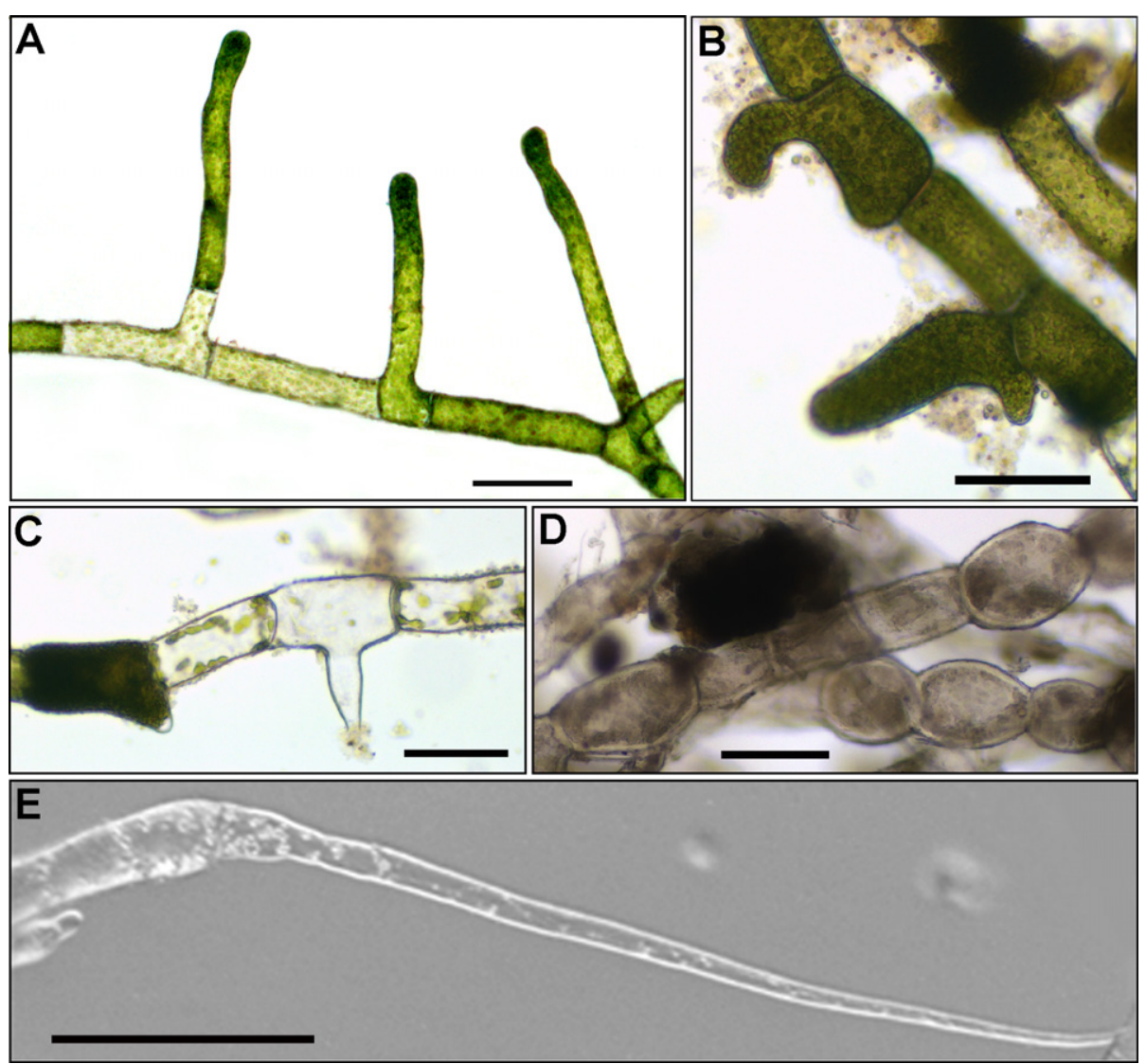

generation but did not produce reproductive structures during the culture experiments. Growth of filaments is much better at salinity of 5 than at salinity of 30 (Fig. S5 in the Supporting Information), and the species appears to be adapted to brackish environments. However, at salinity of 30 , the balsa wood substrate had been fully colonized, while there was very little growth on the two plastic substrates.

Description: Endophytic in mangrove pneumatophores in southern Australia. In culture, a prostrate system of large round cells $(25-50 \mu \mathrm{m}$ diameter) gives rise to an upright system of long thin upright filaments with cylindrical cells (10$20 \mu \mathrm{m}$ diameter), inserted in terminal or central positions and with very delayed cell wall formation. Zoidangia with conspicuous long, terminal exit tubes, sometimes formed in chains.

Etymology: Named after the collection site, southern Australia.

Holotype: endophytic in Avicennia bark, Jawbone Reserve, Victoria, Australia, 09 November 1998, J. A. West, Leiden (L) 0793301 (holotype) \& L 0793300 (isotype). Live culture deposited at the ProvasoliGuillard National Center for Marine Algae and Microbiota (formerly National Center for Culture of Marine Phytoplankton), USA (no. NCMA/ CCMP3465). Sequence data: GenBank KY593943 (ITS rDNA), FR719943 (LSU rDNA), FR719931 (SSU rDNA).
Low molecular weight carbohydrate content. The LMWCs, arabitol, digeneaside, dulcitol, erythritol, glycerol, mannitol, ribitol, sorbitol, and trehalose, were not detected in any sample; sucrose, glucose, and xylose were the only LMWCs present (Table S2). Sucrose was detected in all analyzed samples, and amounts varied considerably between 38 and $692 \mu \mathrm{mol} \cdot \mathrm{g}^{-1}$ dry weight even within species. W. salina was the only species that contained $180-348 \mu \mathrm{mol} \cdot \mathrm{g}^{-1}$ dry weight free glucose and 201-396 $\mu \mathrm{mol} \cdot \mathrm{g}^{-1}$ dry weight free xylose as well, but these two LMWCs were lacking in one out of four samples of $W$. salina (Table S2). This W. salina sample (Q67), however, exhibited the highest sucrose concentration compared to the other three samples. Although sucrose is chemotaxonomically not informative, the presence of glucose and particularly the rather unusual xylose seems to be restricted to $W$. salina.

\section{DISCUSSION}

This is the first well-sampled study of the genus Wittrockiella that includes intraspecific sampling throughout the distribution range of $W$. lyallii and $W$. salina, the distribution range of $W$. salina is extended to the Northern Hemisphere, and two new species have been discovered that are described here. Furthermore, we present the first evidence for 

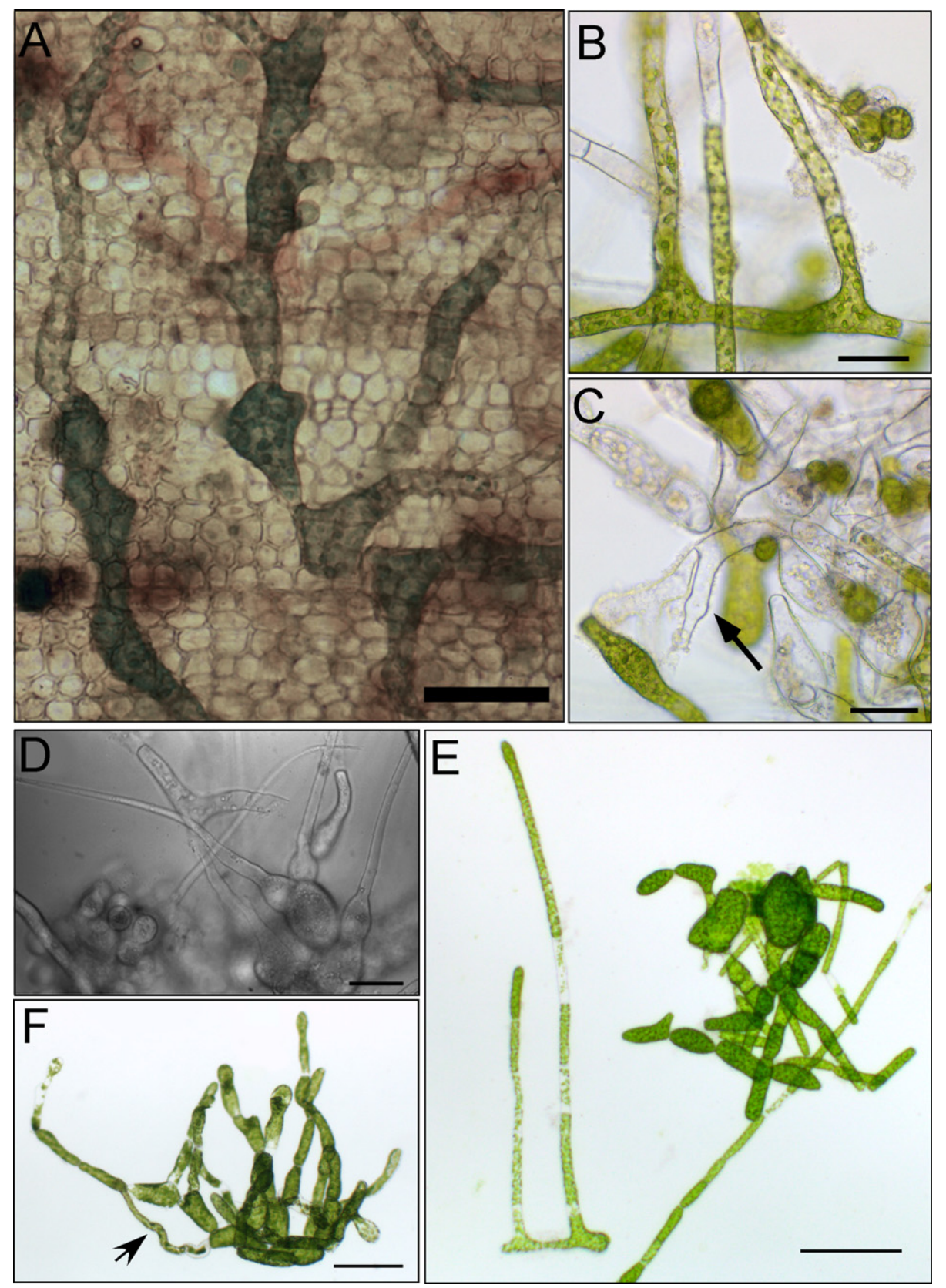

FIG. 5. Morphological features of Wittrockiella zosterae sp. nov. (A) Endophytic filaments of W. zosterae in a dead leaf of Zostera, Washington, USA, scale bar $=100 \mu \mathrm{m}$. Photo: Gretchen Frankenstein. (B, C) Cultured material originally isolated from Zostera leaves, Washington, USA. (B) Prostrate and upright filaments with similar diameters, scale bar $=50 \mu \mathrm{m}$. (C) Empty zoidangium with conspicuous discharge tube (arrow), scale bar $=50 \mu \mathrm{m}$. (D) Hairs on cells from a nutrient-depleted culture, scale bar $=100 \mu \mathrm{m}$. (E, F) Culture material (ACOI 471) previously labeled Wittrockiella calcicola (Cladophorella calcicola), originally isolated from a lagoon in Portugal. (E) Irregular growth in culture: separation into prostrate and upright systems becomes indistinct, strongly varying cell shapes and diameters, many cells are swollen (right), and thin upright filaments (left), scale bar $=200 \mu \mathrm{m}$. (F) Small tuft of prostrate filaments with upright branches, culture material. A terminal secondary rhizoid produced by a prostrate cell is indicated (arrow), scale bar $=$ $200 \mu \mathrm{m}$. sexual reproduction in Wittrockiella and illustrate a case of possible polyploid speciation.

Despite their widespread distribution and occurrence in distant and isolated locations, W. lyallii showed no intraspecific genetic variation in the markers used and samples of W. salina varied only at a single site in the ITS region. For both W. amphibia and $W$. zosterae, only two samples each were available, and they differed by $7 \mathrm{bp}(\sim 0.8 \%)$ and 1 bp $(\sim 0.1 \%)$ in the whole ITS region, respectively. Unfortunately, we are still lacking molecular data for Atlantic populations of W. amphibia, which would be interesting to compare to the Pacific sequences. The ITS region is typically very variable (both ITS1 and ITS2), and frequently shows variation within species. In the marine green algal genera Phyllodictyon and Boodlea (Siphonocladus clade, Cladophorales), sequences of the whole ITS region showed intraspecific variation of up to $4 \%$, and between-clade divergence of $7 \%-29 \%$, with ITS1 and ITS2 displaying similar levels of variability (Leliaert et al. 2008, 2009a). Even higher intraspecific ITS sequence variation of $18 \%-33 \%$ was found in the marine species Cladophora albida and Cladophora vagabunda (Bakker et al. 1992, 1995, Marks and Cummings 1996), but it is likely that these numbers reflect divergence between cryptic species rather than intraspecific variation. In contrast, all samples 
FIG. 6. Morphology of Wittrockiella australis sp. nov. in culture. (A) Growth in culture, unattached entangled mass of thick prostrate filaments with irregular cell shape and size and many swollen cells, and thin upright filaments, scale bar $=$ $200 \mu \mathrm{m}$. (B) Irregularly shaped cells of the prostrate system giving rise to thin upright branches in an unattached, cultured thallus, scale bar $=50 \mu \mathrm{m}$. (C) Attached thallus grown on Nitex mesh after 10 weeks in stationary culture at a salinity of $5(30 \mu \mathrm{mol}$ photons $\left.\mathrm{m}^{-2} \cdot \mathrm{s}^{-1}\right)$, consisting of thick prostrate filaments and few thinner upright filaments. Few empty zoidangia, scale bar = $200 \mu \mathrm{m}$. (D) Attached thallus grown on Nitex mesh after 10 weeks in stationary culture at a salinity of $30 \quad(30 \mu \mathrm{mol}$ photons $\left.\cdot \mathrm{m}^{-2} \cdot \mathrm{s}^{-1}\right)$, consisting mainly of empty zoidangia. Release of zoospores can be seen (arrow), scale bar $=200 \mu \mathrm{m}$. (E) Immature zoidangia with discharge tubes beginning to form (arrows), scale bar $=50 \mu \mathrm{m} . \quad(\mathrm{F})$ Zoidangium formation: extension of the discharge tube (arrow). An empty zoidangium is indicated by a double arrow. Also visible is a small spore attached to thin filament above, scale bar $=50 \mu \mathrm{m}$.

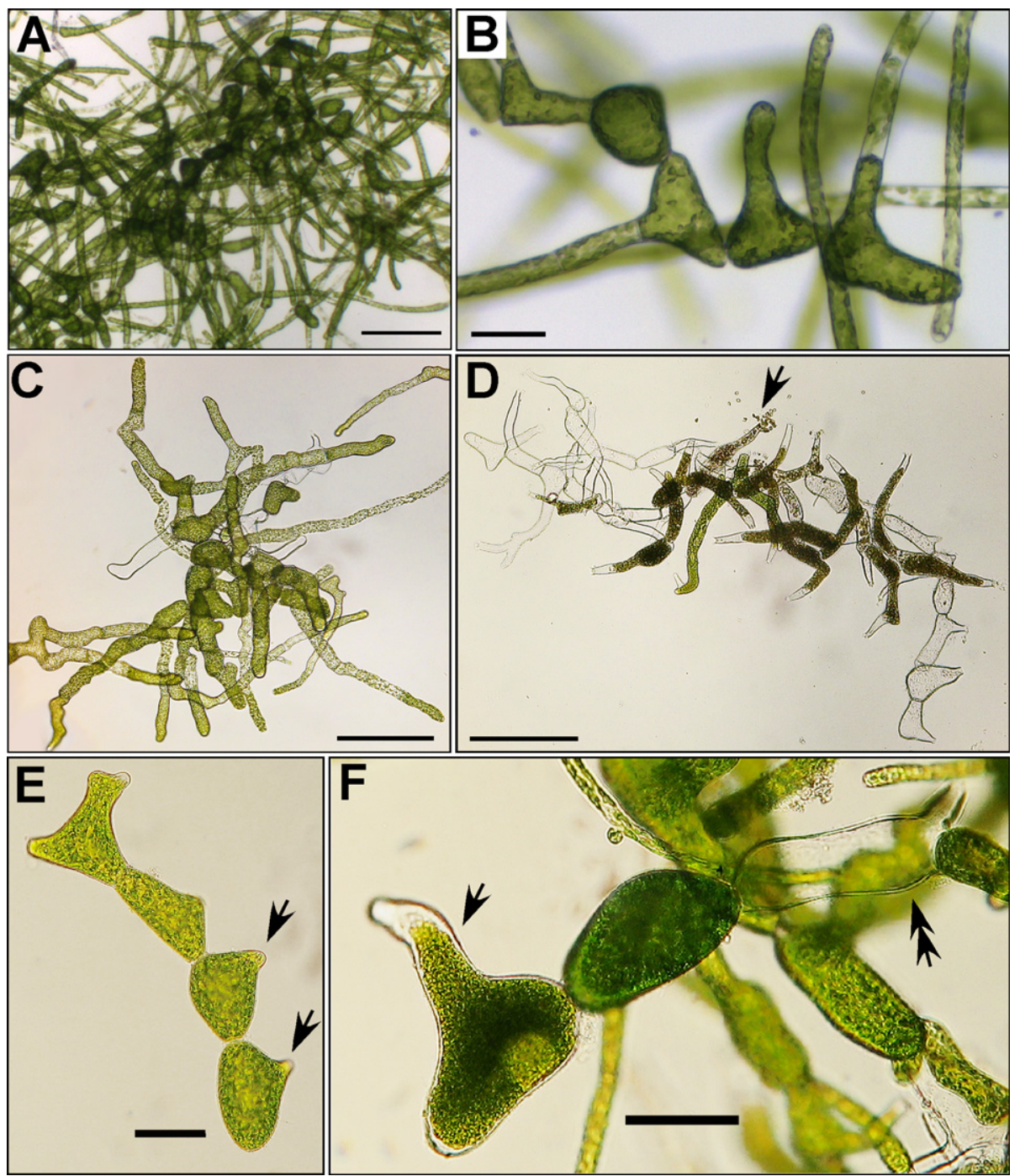

of the common and easily dispersed freshwater alga Cladophora glomerata have identical ITS sequences (Marks and Cummings 1996, Ross 2006). The absence or extremely low levels of genetic variation in W. lyallii and W. salina suggests ongoing gene flow and thus relatively frequent dispersal between populations. It is, however, hard to imagine gene flow in $W$. salina to occur between sandstone cliffs on the New Zealand coast, a freshwater waterfall in the forest on the isolated Lord Howe Island, and brackish lakes in the north of Japan. Neither water currents nor bird migration pattern can explain this observation. The alternative explanation, that low or missing ITS variation does not necessarily mean recent connectivity of populations but low rates of sequence evolution, has been discussed for $W$. lyallii (Boedeker et al. 2010a) and the related freshwater and brackish species A. linnaei (Boedeker et al. 2010c) because of the postulated low dispersal capacity of these species. It will be interesting to investigate the ITS sequences further, to see whether they possibly are structurally reduced to a minimum motif with small loop regions and thus having limited potential for mutations. A dated phylogeny would also be most useful for testing whether the origin and distribution of W. lyallii fits a Gondwana vicariance scenario, and molecular markers other than rDNA that work in the Cladophorales are still not available and need to be developed.

Between Wittrockiella species, the ITS sequences are so different that they cannot be sensibly aligned. Automated secondary structure alignments failed to produce drastically improved alignments and phylogenies, and the degree of variation in ITS sequences between species makes it nearly impossible to identify homologous regions. The phylogenetic trees resulting from the concatenated dataset that included the automated secondary structure alignment of the whole ITS region also did not resolve the basal polytomy, similar to the results when using only the SSU, LSU, und 5.8S data (Figs. 1 and S1). 
Because of the difficulties with aligning homologous regions, we decided to only include the $5.8 \mathrm{~S}$ region rather than the spacers in the main analysis. The low support for the relationships of the three main branches prevents the analysis of biogeographical patterns and speculations on the origin of the genus Wittrockiella. Although there is no or very little intraspecific variation, the genetic distances between species are large (up to $8 \%$ in LSU sequences), which suggests that Wittrockiella is an old genus. Genetically most similar are W. amphibia and $W$. zosterae, which differ by $1.3 \%$ in the LSU and by $14 \%$ in the ITS region. This pair of sister species apparently diverged more recently, possibly via polyploidization as suggested by their chromosome numbers of $n=12$ and $n=24$, respectively.

Despite not all relationships between clades being resolved, all species are well supported. The absence of any sequence differences between W. salina var. kraftii from freshwater environments on Lord Howe Island and the rest of the $W$. salina samples indicates that there is no reason to recognize this variety. This is also supported by the finding of W. salina in freshwater environments in Japan. Apparently, this species has a remarkable capacity to grow in salinities from fully marine to brackish to pure freshwater.

Based on the phylogenetic analyses, two new species are recognized. The three species W. amphibia, $W$. zosterae sp. nov., and $W$. australis sp. nov. form a supported clade and share the same morphology. Although $W$. australis seems to have smaller maximum cell diameters, the ranges of cell dimensions overlap between those three species, and they cannot be distinguished from each other with confidence based on morphology alone. Thus, $W$. australis sp. nov. is described based on molecular data alone, as has been done in other taxa (e.g., Nelson et al. 2005, West et al. 2008, 2014, Sutherland et al. 2011). The recognition of the sister species $W$. amphibia and W. zosterae is additionally supported by their karyological differences, with $W$. zosterae having twice the number of chromosomes of W. amphibia. This suggests polyploid speciation, maybe from autopolyploidy in which the tetraploid species W. zosterae originated from spontaneous genome duplication in W. amphibia (or its ancestor) due to meiotic errors. Polyploidy is common in plants and algae (Nichols 1979, Kapraun 2007, Wood et al. 2009), and frequently leads to instant speciation since the resulting offspring may be reproductively isolated from their parents (Bolnick and Fitzpatrick 2007). It has been indicated that polyploidy is almost universal in the Cladophoraceae, with a basic number of six chromosomes and complements of 12, 18, 24, 30, 36, etc., found in many species (e.g., Godward 1959, Wik-Sjöstedt 1970, Kapraun 2007). This is the first time that evidence is provided for different ploidy levels in two sister species of Cladophorales, hinting at instantaneous speciation by genome duplication.

The alternation of haploid and diploid generations has been shown for both W. amphibia and W. zosterae in this study, which adds to the scarce evidence for sexual reproduction in Wittrockiella and the family Pithophoraceae. Previously, the only other studies that indicated sexual reproduction in the Pithophoraceae are the observations of gametes in Arnoldiella kosterae (C. Hoek) Boedeker (as Cladophora kosterae C. Hoek, in van den Hoek 1963), and of gametes and zygotes in Arnoldiella chelonum (Collins) Boedeker (as Basicladia chelonum (Collins) W.E. Hoffmann \& Tilden, in Hamilton (1948)) and in Basicladia okamurae (S. Ueda) Garbary (as Cladophora okamurai (S. Ueda) C. Hoek, in van den Hoek 1963), plus chromosome counts of $n=11$ and $n=22$ in Aegagropilopsis clavuligera (Grunow) Boedeker (as Cladophora clavuligera Grunow, in Patel (1996)). A. linnaei and Pithophora roettleri (Roth) Wittrock are thought to be asexual species (Boedeker et al. 2010c), and for the remaining species of the Pithophoraceae, including W. lyallii, W. salina, and $W$. australis, sexual reproduction has not been observed and might be rare.

Two new species are described here rather than applying existing names to those two clades. The reason for this is the unreliability of morphological identifications due to overlapping and non-diagnostic characters (Table 2), which makes it impossible to link the different species lineages to available existing names (Tautz et al. 2003, De Clerck et al. 2013, Verbruggen 2014). In the absence of molecular data, the assignment of a sample to existing species names based on morphology would be arbitrary in many cases. Ideally, sequences of the type specimens are needed, and while this is becoming more feasible with technological advances such as next generation sequencing that allows the generation of at least partial DNA sequences of old type specimens (Hughey et al. 2014, Prosser et al. 2016), this is currently often not practically possible. Furthermore, most type specimens of the remaining described Wittrockiella species are missing, and for several even the type locations have been irreversibly altered so that recollections will not be possible. The type specimen of W. calcicola is lost or destroyed (Boedeker et al. 2012), and the type location, limestone rocks in a tropical hothouse in the Cambridge Botanical Garden, UK, does not exist anymore (staff members at Cambridge Botanical Garden, pers. comm.). The name W. calcicola was applied in Boedeker et al. (2012) to material isolated from a lagoon in Portugal (specimen K92/ herbarium voucher L 0793292/culture collection ACOI471; Table S1) that was also used in the present study and actually represents $W$. zosterae (thus, this material does not function as an epitype for $W$. calcicola as was prematurely stated in Boedeker et al. (2012)). As the true identity of the type 
specimen of $W$. calcicola will never be known, it is suggested to discontinue the use of this name. Wittrockiella netzahualpillii is only known from an inland brackish water well in Mexico (Galicia-García and Novelo 2000), which has disappeared since the description of this species (E. Novelo pers. comm.). Wittrockiella netzhualpilii might be found again in another site, and its unique morphological features should allow for correct identification. The type of this species had been preserved in formaldehyde, but high-throughput sequencing approaches might make it possible to generate sequence data from the type specimen at some stage. The two Wittrockiella species described from the Indian subcontinent, W. fritschii (A.K. Islam) Boedeker and W. sundarbanensis (A.K. Islam) Boedeker are only known from the type specimens. These type specimens were kept in the herbarium of A. K. M. N. Islam (Islam 1964), but its whereabouts cannot be traced and it is assumed to be lost (pers. comm. by staff members at the University of Dhaka, Bangladesh, the National Botanical Research Institute, India and the University of Peshawar, Pakistan). As there are no molecular data for W. calcicola, W. fritschii, and W. sundarbanensis, and the type specimens are not available anymore, it is recommended here that these names should not be used anymore, as the identity of the type specimens will remain unknown and assignment by morphology is not possible.

There are three other green algal species with a unique morphology that suggests that they belong to the genus Wittrockiella. Cladophora amplectens Welwitsch occurs on mangrove stems and pneumatophores in Luanda ("Loanda"), Angola, and forms tufts "like a child's head," up to $15 \mathrm{~cm}$ in diameter, with filaments $75-150 \mu \mathrm{m}$ in diameter and "belongs to the section Aegagropila" (West and West 1897). Cladophora dubia Schmidle, forms turfs on rocks in slightly brackish water in Asau ("Assau"), Savai'i, Samoa, and consists of a heterotrichous system with prostrate filaments up to $350 \mu \mathrm{m}$ in diameter and upright filaments up to $200 \mu \mathrm{m}$ in diameter, also the formation of spurs and rhizoids ending in haptera has been described (Reinecke 1897). Bolbocoleon jolyi Yamaguishi-Tomita is a large-celled (up to $150 \mu \mathrm{m}$ diameter) marine alga from Brazil with reticulate chloroplasts that occurs on sand and bears bulbous-based hairs (Yamaguishi-Tomita 1970). Bolbocoleon piliferum, the type and only other species of the genus, Bolbocoleon, is a much smallercelled, uninucleate alga belonging to the order Ulvales (O'Kelly et al. 2004). Since these taxa have either unique morphological features or occur in unique habitats, there is a possibility that they will be recollected and assigned to those names. The transfer of these taxa to Wittrockiella should be made once sequence data are available and confirm their taxonomic placement. Wittrockiella (or Cladophorella) has also been reported from tropical Queensland, Australia (Cribb 1965) and from the Caribbean (van den Hoek et al. 1984), and those specimens are likely to represent additional species of Wittrockiella.

Despite the simple morphology in Wittrockiella, the function of the few morphological features remains poorly understood. In this study, evidence is provided for the occurrence of hairs in W. amphib$i a$ and $W$. zosterae, and hairs had been reported in the literature for $W$. amphibia (as W. paradoxa; Wille 1909, Printz 1927, Polderman 1976, South 1981) and also for W. salina (van den Hoek et al. 1984). Hairs are an unusual feature for the Cladophorales, and have not been reported for any other genus of the order. Both septate (Printz 1927, South 1981) and non-septate hairs (Polderman 1976, van den Hoek et al. 1984, this study) have been observed. The function of the unpigmented hairs is most likely to increase the surface area in order to facilitate nutrient uptake (as shown in cyanobacteria; Sinclair and Whitton 1977, in the red alga Spyridia; O'Connor and West 1991, or in green algae; Whitton and Harding 1978), which is supported by their development in nutrient-depleted cultures. Akinetes and akinete-like structures have been reported for a number of species of Wittrockiella, but it is not always clear what those enlarged cells really represent. Akinetes or swollen cells (sometimes also referred to as "spurs," "knee cells," or "dorsal projections") have been documented either to occur singly or in short chains in W. amphibia (Collins 1907, Wille 1909, South 1981, 1989, Boedeker and Hansen 2010, this study), W. calcicola (Fritsch 1944), W. fritschii (Islam 1964), W. netzhualpilii (Galicia-García and Novelo 2000), W. salina (Chapman 1949), and W. sundarbanensis (Islam 1964). The immature zoidangia of W. australis (Fig. 6E) show similar dorsal projection, but might have developed from a regular vegetative cell rather than from an akinete. Without following the development of cells, it can be difficult to distinguish between akinetes and immature zoidangia, between the formation of a branch or rhizoid or an elongated exit tube, and even between empty zoidangia and cells infected by fungi (e.g., Blodgettia infections, Sakai 1964). The nature of the akinetelike cells in Wittrockiella seems to be similar to the characteristic akinetes of Pithophora. In Pithophora, the size, shape, and arrangement of akinetes are not stable but are controlled by environmental conditions. Akinete germination is inducible by various external factors (Ernst 1908, Agrawal 1986, Stevens and Neilson 1987), and akinete and branch formation are the same, reversible process (Mothes 1930). It seems that in Wittrockiella akinetes can either transform into a sporangium or germinate into a branch, but more culture observations are needed. Interestingly, the elongated exit tubes form on a zoidangium long before spores or gametes are formed inside, so in fact the origin might be related to akinete germination and branch formation.

The elongated discharge tubes might represent an adaptation for endophytes (W. amphibia; 
Polderman 1976, W. australis and W. zosterae; this study) or to frequent burial (W. amphibia, see also Boedeker and Hansen 2010), and thus ensure that the spores or gametes reach the surrounding water. Members of Wittrockiella are typically found semi-terrestrially (on moist stone or on mud), or in estuarine or intertidal habitats that are characterized by high fluctuations of environmental parameters and by frequently reduced salinities due to freshwater seepage or river inflow. The preference for brackish habitats is not fully explained by reduced competition in stressful environments (Boedeker 2010), as the new species $W$. australis germinated and grew much better in low salinity media compared to seawater in culture experiments (Fig. S5 in the Supporting Information). However, at a salinity of 30 , the balsa wood substrate was fully colonized (Fig. S5), suggesting that other factors than salinity alone influence the occurrence of this species. W. salina occupies a remarkably broad salinity range, as identical ITS genotypes have been found in pure freshwater environments on Lord Howe Island (Australia), in brackish lakes on Honshu (Japan) and in the marine intertidal in New Zealand. Possible adaptations of Wittrockiella to habitats with fluctuating salinities include the formation of a thick mucilage layer in W. amphibia (Wille 1909) and the cushion-like growth habit to preserve moisture during exposure to air in W. salina and W. lyallii. Also the endophytic lifestyle in W. amphibia, $W$. australis $W$. zosterae, and $W$. zosterae can be viewed in the same way, as it protects the algal filaments from drastic and abrupt changes in salinity. The heterotrichous thalli of Wittrockiella could also represent an adaptation to harsh environments. Fritsch (1944) regarded the heterotrichous habit of W. calcicola as an adaptation to growth on semi-terrestrial rock surfaces. The prostrate system is generally more sheltered from desiccation and abrasion (Fritsch 1945, Seapy and Littler 1982, Littler and Kauker 1984, Boedeker 2010).

More culture studies, studies on development, and crossing experiments are likely to yield important additional insights into the biology of Wittrockiella, and more sampling and sequence data from green filaments from freshwater and brackish environments, especially in the tropics, will probably reveal additional diversity in Wittrockiella. Here, we established a phylogeny-based taxonomy that can be added to as new sequence data will become available.

Many people helped with making this study possible, by collecting (or trying!) and providing specimens or by facilitating access to herbarium specimens, sites, and crucial information. We are grateful to Graham Bell, Wendy K. Bellows, Elizabeth Brown, Jenny Bryant, Jennifer Dalen, Dale Dixon, Roberta D'Archino, Tim Entwisle, Catherine Gallagher, Gayle I. Hansen, Jo Hiscock, Lucy Jack, Frederik Leliaert, Pete McClelland, Alan Millar, Wendy A. Nelson, Eberto Novelo, Christopher R. Omelon, Willem Prud'homme van Reine,
María Eliana Ramírez, Stephen Skinner, Michael Stech, David Thompson, Jo Wilbraham, Sarah Wilcox, and Brian Wysor. The following people on Lord Howe Island are thanked for their help with permits, site access, and waiving fees: Hank Bower, Christo Haselden, Sallyann Gudge, Dave Kelly, Ian Kerr, Terry Wilson, with special extra thanks to Sue Bower for a successful hike to the type location of W. salina var. kraftii at Dinner Run. Technical assistance was provided by Bertie van Heuven and Juliane Müller. CB acknowledges the German Academic Exchange Service (DAAD) and the Royal Society of New Zealand (Marsden Fund) for postdoctoral scholarships.

\section{CONFLICTS OF INTEREST}

All authors declare that there is no conflict of interest.

Adams, N. M. 1994. Seaweeds of New Zealand. An Illustrated Guide. Canterbury University Press, Christchurch, 360 pp.

Agrawal, S. C. 1986. Effects of different factors on the akinete germination of Pithophora oedogonia. J. Basic Microbiol. 26:195-9.

Bakker, F. T., Olsen, J. L. \& Stam, W. T. 1995. Global phylogeography in the cosmopolitan species Cladophora vagabunda (Chlorophyta) based on nuclear rDNA internal transcribed spacer sequences. Eur. J. Phycol. 30:197-208.

Bakker, F. T., Olsen, J. L., Stam, W. T. \& van den Hoek, C. 1992. Nuclear rDNA internal transcribed spacer regions (ITS1 and ITS2) define discrete biogeographic groups in Cladophora albida (Chlorophyta). J. Phycol. 28:839-45.

Beanland, W. R. \& Woelkerling, W. J. 1982. Studies on Australian mangrove algae: II. Composition and geographic distribution of communities in Spencer Gulf, South Australia. Proc. R. Soc. Vic. 94:89-106.

Boedeker, C. 2010. Phylogenetic, taxonomic and biogeographical studies in the Pithophoraceae (Cladophorales, Chlorophyta). $\mathrm{PhD}$ thesis, Netherlands Centre for Biodiversity Naturalis, Leiden, 223 pp.

Boedeker, C., Eggert, A., Immers, A. \& Smets, E. 2010b. Global decline of and threats to Aegagropila linnaei, with special reference to the lake ball habit. Bioscience 60:187-98.

Boedeker, C., Eggert, A., Immers, A. \& Wakana, I. 2010c. Biogeography of Aegagropila linnaei (Cladophorophyceae, Chlorophyta): a widespread freshwater alga with low effective dispersal potential shows a glacial imprint in its distribution. J. Biogeogr. 37:1491-503.

Boedeker, C. \& Hansen, G. I. 2010. Nuclear rDNA sequences of Wittrockiella amphibia (Collins) comb. nov. (Cladophorales, Chlorophyta) and morphological characterisation of the mat-like growth form. Bot. Mar. 53:351-6.

Boedeker, C., Leliaert, F. \& Zuccarello, G. C. 2016. Molecular phylogeny of the Cladophoraceae (Cladophorales, Ulvophyceae), with the resurrection of Acrocladus Nägeli and Willeella Børgesen, and the description of Lubrica gen. nov. and Pseudorhizoclonium gen. nov. J. Phycol. 52:905-28.

Boedeker, C., O'Kelly, C. J., Star, W. \& Leliaert, F. 2012. Molecular phylogeny and taxonomy of the Aegagropila clade (Cladophorales, Chlorophyta), including the description of Aegagropilopsis gen. nov. and Pseudocladophora gen. nov. J. Phycol. 48:808-25.

Boedeker, C., Ramírez, M. E. \& Nelson, W. A. 2010a. Cladophoropsis brachyartra from southern South America is a synonym of Wittrockiella lyallii (Cladophorophycaeae, Chlorophyta), previously regarded as endemic to New Zealand. Phycologia 49:525-36.

Bolnick, D. I. \& Fitzpatrick, B. M. 2007. Speciation: sympatric models and empirical evidence. Annu. Rev. Ecol. Evol. Syst. 38:459-87.

Calvo, S., Bárbara, I. \& Cremades, J. 1999. Benthic algae of saltmarshes (Corrubedo Natural Park, NW Spain): the flora. Bot. Mar. 42:343-53. 
Chapman, V. J. 1949. Some new species and forms of marine algae from New Zealand. Farlowia 3:495-8.

Chapman, V. J. 1956. The marine algae of New Zealand. Part I. Myxophyceae and Chlorophyceae. J. Linn. Soc. London, Bot. 55:333-501.

Chappell, D. F., O’Kelly, C. J. \& Floyd, L. 1991. Flagellar apparatus of the biflagellate zoospores of the enigmatic marine green alga Blastophysa rhizopus. J. Phycol. 27:423-8.

Collins, F. S. 1907. Some new green algae. Rhodora 9:198-200.

Collins, F. S. 1912. The green algae of North America, supplementary paper. Tufts Coll. Stud. 3:69-109.

Cribb, A. B. 1965. An ecological and taxonomic account of the algae of a semi-marine cavern, Paradise Cave, Queensland. Papers Dept. Bot. Univ. Queensland 4:259-82.

De Clerck, O., Guiry, M. D., Leliaert, F., Samyn, Y. \& Verbruggen, H. 2013. Algal taxonomy: a road to nowhere? J. Phycol. 49:215-25.

Edgar, R. C. 2004. MUSCLE: multiple sequence alignment with high accuracy and high throughput. Nucleic Acids Res. 32:1792-7.

Ernst, A. 1908. Beitrag zur Morphologie und Physiologie von Pithophora. Ann. Jard. Bot. Buitenzorg 22:18-29.

Felsenstein, J. 1985. Confidence limits on phylogenies: an approach using the bootstrap. Evolution 39:783-91.

Fritsch, F. E. 1935. The structure and reproduction of the algae. Volume I. Introduction, Chlorophyceae. Xanthophyceae, Chrysophyceae, Bacillariophyceae, Cryptophyceae, Dinophyceae, Chloromonineae, Euglenineae, Colourless Flagellata. Cambridge University Press, Cambridge, $791 \mathrm{pp}$.

Fritsch, F. E. 1944. Cladophorella calcicola nov. gen. et sp., a terrestrial member of the Cladophorales. Ann. Bot. 8:157-71.

Fritsch, F. E. 1945. Studies in the comparative morphology of the algae. IV. Algae and archegoniate plants. Ann. Bot. 9:1-29.

Galicia-García, C. \& Novelo, E. 2000. Cladophorella netzhualpilii sp. nov. (Cladophorales, Ulvophyceae), a species reproducing by spores. Phycologia 39:288-95.

Godward, M. B. E. 1959. Chromosome numbers in the algae II Chlorophyta (1). Eur. J. Phycol. 1:43-6.

Goff, L. \& Moon, D. 1993. PCR amplification of nuclear and plastid genes from algal herbarium specimens and algal spores. J. Phycol. 29:381-4.

Guillard, R. R. L. \& Ryther, J. H. 1962. Studies of marine planktonic diatoms. I. Cyclotella nana Hustedt and Detonula confervacea Cleve. Can. J. Microbiol. 8:229-39.

Hamilton, J. M. 1948. Sexual reproduction in the genus Basicladia (Thallophyta, Chlorophyceae). Trans. Am. Microsc. Soc. 67:201-5.

Hanyuda, T., Wakana, I., Arai, S., Miyaji, K., Watano, Y. \& Ueda, K. 2002. Phylogenetic relationships within Cladophorales (Ulvophyceae, Chlorophyta) inferred from 18S rRNA gene sequences, with special reference to Aegagropila linnaei. J. Phycol. 38:564-71.

Hardy, F. G. \& Guiry, M. D. 2003. A Check-list and Atlas of the Seaweeds of Britain and Ireland, 2nd edn. British Phycological Society, London, $435 \mathrm{pp}$.

Hassouna, N., Michot, B. \& Bachellerie, J. P. 1984. The complete nucleotide sequence of mouse $28 \mathrm{~S}$ rRNA gene. Implications for the process of size increase of the large subunit rRNA in higher eukaryotes. Nucleic Acids Res. 12:3563-83.

Hayakawa, Y. I., Ogawa, T., Yoshikawa, S., Ohki, K. \& Kamiya, M. 2012. Genetic and ecophysiological diversity of Cladophora (Cladophorales, Ulvophyceae) in various salinity regimes. Phycol. Res. 60:86-97.

van den Hoek, C. 1963. Revision of the European species of Cladophora. Brill E. J., Leiden, Netherlands, 248 pp.

van den Hoek, C., Ducker, S. C. \& Womersley, H. B. S. 1984. Wittrockiella salina Chapman (Cladophorales, Chlorophyceae), a mat and ball forming alga. Phycologia 23:39-46.

van den Hoek, C. \& Womersley, H. B. S. 1984. Genus Cladophora. In Womersley, H. B. S. [Ed.] The Marine Benthic Flora of Southern Australia. Part I. Government Printer, Adelaide, pp. 185-213.

Hughey, J., Gabrielson, P. W., Rohmer, L., Tortolani, J., Silva, M., Miller, K. A., Young, J. D., Martell, C. \& Ruediger, E. 2014.
Minimally destructive sampling of type specimens of Pyropia (Bangiales, Rhodophyta) recovers complete plastid and mitochondrial genomes. Sci. Rep. 4:5113.

Ichihara, K., Shimada, S. \& Miyaji, K. 2013. Systematics of Rhizoclonium-like algae (Cladophorales, Chlorophyta) from Japanese waters, based on molecular phylogenetic and morphological analyses. Phycologia 52:398-410.

Islam, A. K. M. N. 1964. The genus Cladophorella newly found in East Pakistan. Rev. Algol. 7:275-89.

Kapraun, D. F. 2007. Nuclear DNA content estimates in green algal lineages: Chlorophyta and Streptophyta. Ann. Bot. 99:677-701.

Karsten, U., Michalik, D., Michalik, M. \& West, J. A. 2005. A new unusual low molecular weight carbohydrate in the red algal genus Hypoglossum (Delesseriaceae, Ceramiales) and its possible function as an osmolyte. Planta 222:319-26.

Karsten, U., Thomas, D. N., Weykam, G., Daniel, C. \& Kirst, G. O. 1991. A simple and rapid method for extraction and separation of low molecular-weight carbohydrates from macroalgae using high performance liquid-chromatography. Plant Physiol. Biochem. 29:373-8.

Katoh, K., Kuma, K., Toh, H. \& Miyata, T. 2005. MAFFT version 5: improvement in accuracy of multiple sequence alignment. Nucleic Acids Res. 33:511-8.

Leliaert, F. \& Boedeker, C. 2007. Cladophorales. In Brodie, J., Maggs, C. A. \& John, D. [Eds.] Green Seaweeds of Britain and Ireland. Natural History Museum Publications, London, UK, pp. 131-83.

Leliaert, F., De Clerck, O., Verbruggen, H., Boedeker, C. \& Coppejans, E. 2007. Molecular phylogeny of the Siphonocladales (Chlorophyta: Cladophorophyceae). Mol. Phylogen. Evol. 44:1237-56.

Leliaert, F., Rousseau, F., de Reviers, B. \& Coppejans, E. 2003. Phylogeny of the Cladophorophyceae (Chlorophyta) inferred from partial LSU rRNA gene sequences: is the recognition of a separate order Siphonocladales justified? Eur. J. Phycology 38:233-46.

Leliaert, F., Rueness, J., Boedeker, C., Maggs, C. A., Cocquyt, E., Verbruggen, H. \& De Clerck, O. 2009b. Systematics of the marine microfilamentous green algae Uronema curvatum and Urospora microscopica (Chlorophyta). Eur. J. Phycol. 44:487-96.

Leliaert, F., Verbruggen, H., Wysor, B. \& De Clerck, O. 2009a. DNA taxonomy in morphologically plastic taxa: algorithmic species delimitation in the Boodlea complex (Chlorophyta: Cladophorales). Mol. Phylogen. Evol. 53:122-33.

Leliaert, F., Wysor, B., Verbruggen, H., Vlaeminck, C. \& De Clerck, O. 2008. Phyllodictyon robustum (Setchell et Gardner) comb. nov. (Siphonocladales, Chlorophyta), a morphologically variable species from the tropical Pacific coast of America. Crypt. Algol. 29:217-33.

Littler, M. M. \& Kauker, B. J. 1984. Heterotrichy and survival strategies in the red alga Corallina officinalis. Bot. Mar. 27:3744.

Liu, G. 1999. Study on the systematics of freshwater Cladophoraceae from China. MSc thesis, Institute of Hydrobiology, Chinese Academy Sciences, Wuhan, 117 pp.

Marks, J. C. \& Cummings, M. P. 1996. DNA sequence variation in the ribosomal internal transcribed spacer region of freshwater Cladophora species. J. Phycol. 32:1035-42.

Mothes, K. 1930. Morphologishe und physiologische Studien an der Cladophoracee Pithophora. Ber. Deut. Bot. Ges. 48:110-21.

Nelson, W. A., Farr, T. J. \& Broom, J. E. S. 2005. Dione and Minerva, two new genera from New Zealand circumscribed for basal taxa in the Bangiales (Rhodophyta). Phycologia 44:13945 .

Nelson, W. A., Villouta, E., Neill, K., Williams, G. C., Adams, N. M. \& Slivsgaard, R. 2002. Marine macroalgae of Fiordland. Tuhinga 13:117-52.

Nichols, H. W. 1979. Polyploidy in algae. Basic Life Sci. 13:151-61.

Niiyama, Y. 1989. Morphology and classification of Cladophora aegagropila (L.) Rabenhorst in Japanese lakes. Phycologia 28:70-6. 
O'Connor, K. A. \& West, J. A. 1991. The effect of light and nutrient conditions on hair cell formation in Spyridia filamentosa (Wulfen) Harvey (Rhodophyta). Bot. Mar. 34:359-64.

O'Kelly, C. J. 1982. Chloroplast pigments in selected marine Chaetophoraceae and Chaetosiphonaceae (Chlorophyta): the occurrence and significance of siphonaxanthin. Bot. Mar. 25:133-7.

O’Kelly, C. J., Bellows, W. K. \& Wysor, B. 2004. Phylogenetic position of Bolbocoleon piliferum (Ulvophyceae, Chlorophyta): evidence from reproduction, zoospore and gamete ultrastructure, and SSU ribosomal RNA gene sequence. J. Phycol. 40:209-22.

O'Kelly, C. J. \& Floyd, G. L. 1981. The taxonomic position of Chaetosiphon and Wittrockiella (Chaetosiphonaceae, Chlorophyta).J. Phycol. 17:14.

O'Kelly, C. J. \& Floyd, G. L. 1984. Correlations among patterns of sporangial structure and development, life histories, and ultrastructural features in the Ulvophyceae. In Irvine, D. E. G. \& John, D. M. [Eds.] The Systematics of the Green Algae. Syst. Assoc. Spec. Vol. 27, Academic Press, London, pp. 121-56.

Patel, R. J. 1996. Karyological studies of Indian Cladophorales an appraisal. In Chaudhary, B. R. \& Agrawal, S. B. [Eds.] Cytology, Genetics and Molecular Biology of Algae. SPB Academic Publishing, Amsterdam, pp. 73-93.

Polderman, P. J. G. 1976. Wittrockiella paradoxa Wille (Cladophoraceae) in n.w. European saltmarshes. Hydrobiol. Bull. 10:98-103.

Printz, H. 1927. Chlorophyceae. In Engler, A. \& Prantl, K. [Eds.] Die natürlichen Pflanzenfamilien. Wilhelm Engelmann, Leipzig, pp. 1-463.

Prosser, S. W., Dewaard, J. R., Miller, S. E. \& Hebert, P. D. 2016. DNA barcodes from century-old type specimens using nextgeneration sequencing. Mol. Ecol. Res. 16:487-97.

Rambaut, A. 2007. Se-Al (multiple sequence alignment program), v2.0a11. Available at: http://tree.bio.ed.ac.uk/software/sea (last accessed 24 June 2016).

Rambaut, A. 2008. FigTree v.1.1.2. Available at: http://tree.bio.e d.ac.uk/software/figtree/ (last accessed 24 June 2016).

Rambaut, A. \& Drummond, A. J. 2007. Tracer v1.4. Available at: http://tree.bio.ed.ac.uk/software/tracer (last accessed 24 June 2016).

Reinecke, F. 1897. Die Flora der Samoa-Inseln. Engler's Bot. Jahrb. 23:237-368

Ronquist, F. \& Huelsenbeck, J. P. 2003. MRBAYES 3: Bayesian phylogenetic inference under mixed models. Bioinformatics 19:1572-4.

Ross, S. J. 2006. Molecular phylogeography and species discrimination of freshwater Cladophora (Cladophorales, Chlorophyta) in North America. MSc thesis, University of Waterloo, Canada, 155 pp.

Sakai, Y. 1964. The species of Cladophora from Japan and its vicinity. Sci. Pap. Inst. Algol. Res. Fac. Sci. Hokkaido Imp. Univ. 5:1-104.

Seapy, R. R. \& Littler, M. M. 1982. Population and species diversity fluctuations in a rocky intertidal community relative to severe aerial exposure and sediment burial. Mar. Biol. 71:87-96.

Sinclair, C. \& Whitton, B. A. 1977. Influence of nutrient deficiency on hair formation in the Rivulariaceae. Br. Phycol. J. 12:297-313.

Skinner, S. \& Entwisle, T. J. 2004. Non-marine algae of Australia: 6. Cladophoraceae (Chlorophyta). Telopea 10:731-48.

South, G. R. 1981. Wittrockiella paradoxa Wille (Chlorophyta, Cladophoraceae), new for the Pacific coast of North America. Syesis 14:93-5.

South, G. R. 1989. Occurrence of Wittrockiella paradoxa Wille (Chlorophyta, Cladophoraceae) in northeastern North America. Rhodora 91:235-8.

Stamatakis, A. 2014. RAxML Version 8: a tool for phylogenetic analysis and post-analysis of large phylogenies. Bioinformatics 30:1312-3. doi:10.1093/bioinformatics/btu033.

Stevens, R. J. J. \& Neilson, M. A. 1987. Environmental control of Pithophora oedogonia (Chlorophyceae) akinete germination. J. Phycol. 16:424-7.

Sutherland, J. E., Lindstrom, S. C., Nelson, W. A., Brodie, J., Lynch, M. D., Hwang, M. S., Choi, H. G. et al. 2011. A new look at an ancient order: generic revision of the Bangiales (Rhodophyta). J. Phycol. 47:1131-51.

Svedelius, N. 1900. Algen aus den Ländern der Magellansstrasse und West Patagonien. Svenska Exped. Magellansländerna 3:283-316.

Swofford, D. L. 2002. PAUP*. Phylogenetic Analysis Using Parsimony (*and Other Methods), Version 4. Sinauer Associates, Sunderland, Massachusetts.

Tautz, D., Arctander, P., Minelli, A., Thomas, R. H. \& Vogler, A. P. 2003. A plea for DNA taxonomy. Trends Ecol. Evol. 18:70-4.

Verbruggen, H. 2014. Morphological complexity, plasticity, and species diagnosability in the application of old species names in DNA-based taxonomies. J. Phycol. 50:26-31.

West, J. A., Loiseaux de Goër, S. \& Zuccarello, G. C. 2014. A new species of Bangiopsis: B. franklynottii sp. nov. (Stylonematophyceae, Rhodophyta) from Australia and India and comments on the genus. Algae 29:101-9.

West, J. A., Scott, J. L., West, K. A., Clayden, S. L. \& Saunders, G. W. 2008. Rhodachlya madagascarensis gen. et sp. nov.: a distinct acrochaetioid represents a new order and family (Rhodachlyales ord. nov., Rhodachlyaceae fam. nov.) of the Florideophyceae (Rhodophyta). Phycologia 47:203-12.

West, W. \& West, G. S. 1897. Welwitsch's African freshwater algae. J. Bot 35:1-7, 33-42, 77-89, 113-122, 172-183, 235-243, 264 272, 297-304.

White, T. J., Bruns, T., Lee, S. \& Taylor, J. 1990. Amplification and direct sequencing of fungal ribosomal genes for phylogenetics PCR protocols. In Innis, M. A., Gelfand, D. H., Sninsky, J. J. \& White, T. J. [Eds.] A Guide to Molecular Methods and Applications. Academic Press, New York, pp. 315-22.

Whitton, B. A. \& Harding, J. P. C. 1978. Influence of nutrient deficiency on hair formation in Stigeoclonium. Br. J. Phycol. 13:65-8.

Wik-Sjöstedt, A. 1970. Cytogenetic investigations in Cladophora Hereditas 66:233-62.

Wille, N. 1909. Algologische Notizen XV. Über Wittrockiella nov. gen. Nyt Mag. Naturvidensk. 47:209-25.

Wittmann, W. 1965. Aceto-iron-haematoxylin-chloral hydrate for chromosome staining. Stain Technol. 40:161-4.

Wood, T. E., Takebayashi, N., Barker, M. S., Mayrose, I., Greenspoon, P. B. \& Rieseberg, L. H. 2009. The frequency of polyploid speciation in vascular plants. Proc. Natl. Acad. Sci. USA 106:13875-9.

Yamaguishi-Tomita, N. 1970. Bolbocoleon jolyi, a new species of Chaetophoraceae (Chlorophyceae) from Redonda Island, Abrolhos, eastern Brazil. Phycologia 9:125-32.

Yoshii, Y., Hanyuda, T., Wakana, I., Miyaji, K., Arai, S., Ueda, K. \& Inouye, I. 2004. Carotenoid compositions of Cladophora balls (Aegagropila linnaei) and some members of the Cladophorales (Ulvophyceae, Chlorophyta): their taxonomic and evolutionary implication. J. Phycol. 40:1170-7.

\section{Supporting Information}

Additional Supporting Information may be found in the online version of this article at the publisher's web site:

Figure S1. Maximum likelihood phylogram based on a concatenated, partitioned SSU-LSU$5.8 \mathrm{~S}$ alignment of 23 taxa (two ingroup taxa with missing data were excluded).

Figure S2. Bayesian Inference phylogram based on a concatenated, partitioned SSU-LSU-ITS alignment of all 25 taxa. The ITS sequences were aligned using an automated secondary structure based algorithm (MAFFT). 
Figure S3. Sexual reproduction in Wittrockiella amphibia: spores, gametes and chromosomes. (A) Quadriflagellate zoospore, scale bar $=5 \mu \mathrm{m}$. (B) Biflagellate gamete, scale bar $=5 \mu \mathrm{m}$. (C) Prometaphase plate in vegetative cell, gametophytic individual. Chromosome number $n=12 \pm 1$, scale bar $=1 \mu \mathrm{m}$. (D) Prometaphase plate in vegetative cell, gametophytic individual. Chromosome number $n=12 \pm 1$, scale bar $=1 \mu \mathrm{m}$. (E) Prometaphase plate in vegetative cell, progeny of cross between two gametophytes. Chromosome number $n=24 \pm 2$, scale bar $=1 \mu \mathrm{m}$. (F) Prometaphase plate in vegetative cell, progeny of cross between two gametophytes. Chromosome number $n=24 \pm 2$, scale bar $=1 \mu \mathrm{m}$.

Figure S4. Sexual reproduction in Wittrockiella zosterae sp. nov. (A) Quadriflagellate zoospore; only two flagella, and a portion of a third (arrow) are in the plane of focus, scale bar $=5 \mu \mathrm{m}$. (B) Late prophase chromosome squash from a haploid thallus. Chromosome number $n=24 \pm 2$, scale bar $=2 \mu \mathrm{m}$. (C) Metaphase plate from a diploid thallus. Chromosome number $2 n=48 \pm 4$, scale bar $=1 \mu \mathrm{m}$.

Figure S5. Comparison of growth of Wittrockiella australis sp. nov. filaments after 10 weeks in stationary culture under different salinity treat- ments. Well 5 (bottom center) contains a balsa wood chip as substrate, well 6 (bottom right) contains a synthetic mesh as substrate. (A) Low salinity treatment (5 psu): many large tufts have developed in all wells. Neither the balsa wood chip nor the mesh have been preferentially colonized. (B) Full marine salinity treatment (30 psu): very few large tufts have developed. The balsa wood chip has been fully colonized. (C) Number of colonies of $\mathrm{W}$. australis sp. nov. that developed over 6 weeks under different culture conditions. Dark grey bars represent the low salinity treatment (5 psu), light grey bars represent the high salinity treatment (30 psu). Additional culture treatments (stationary vs. shaker culture, low vs. high irradiance $(=5$ vs. $30 \mu \mathrm{mol}$ photons $\cdot \mathrm{m}^{-2} \cdot \mathrm{s}^{-1}$ ) are indicated on the $x$-axis. Values are expressed as means with standard deviations indicated by error bars.

Table S1. List of all investigated Wittrockiella specimens with collection information. n.i. $=$ no information.

Table S2. Low molecular weight carbohydrate content $\left(\mu \mathrm{M} \cdot \mathrm{g}^{-1}\right.$ dry weight) in Wittrockiella species. 